Jakub Niedbalski, Uniwersytet Łódzki

Izabela Ślęzak, Uniwersytet Łódzki

DOI: https://doi.org/10.18778/1733-8069.8.1.07

\title{
ANALIZA DANYCH JAKOŚCIOWYCH PRZY \\ UŻYCIU PROGRAMU NVIVO \\ A ZASTOSOWANIE PROCEDUR METODOLOGII TEORII UGRUNTOWANEJ
}

Abstrakt Celem artykułu jest wskazanie możliwości oraz ograniczeń programów typu CAQDAS (Computer-Assisted Qualitative Data Analysis Software) w zakresie realizacji badań jakościowych. Nasze rozważania opieramy na osobistych doświadczeniach zdobytych podczas realizacji badań prowadzonych zgodnie z zasadami metodologii teorii ugruntowanej (MTU) i z wykorzystaniem programu NVivo w wersji 8 . W artykule rozważamy problem wpływu nowoczesnego oprogramowania CAQDAS reprezentowanego przez program NVivo 8 na sposób organizowania i realizacji badań jakościowych, prowadzonych zgodnie z procedurami TU. Prezentujemy także najważniejsze - naszym zdaniem - funkcje dostępne w programie NVivo 8 i wskazujemy ich aplikacyjny charakter w badaniach opartych na metodologii teorii ugruntowanej.

Słowa kluczowe CAQDAS (Computer-Assisted Qualitative Data Analysis Software), NVivo 8 metody jakościowe, metodologia teorii ugruntowanej

Jakuib Niedbalski, asystent w Instytucie

Socjologii UŁ. Zajmuje się badaniem zachowań i relacji międzyludzkich dotyczących osób niepełnosprawnych. Jego zainteresowania naukowo-badawcze ogniskują się wokół metod jakościowych, symbolicznego interakcjonizmu, ZZL socjologii organizacji oraz polityki społecznej i pracy socjalnej, a także zastosowania nowych technologii w badaniach jakościowych.

Dane adiresowe autora:

Katedra Socjologii Organizacji i Zarządzania,

Instytut Socjologii UŁ

ul. Rewolucji 1905 r. 41, 90-214 Łódź

e-mail: jakub.niedbalski@gmail.com
Powstanie, rozwój i wykorzystanie programów komputerowych w analizie jakościowej

$\mathrm{W}$

raz z rozwojem procesów komputeryzacji i informatyzacji oraz upowszechnianiem się nowoczesnych technologii w kolejnych dyscyplinach naukowych przed badaczami otwierają się nowe sposoby i możliwości realizacji projektów badawczych. Oceniając to zjawisko z perspektywy historycznej, można zauważyć, że szansę tę jako pierwsi dostrzegli przedstawiciele nauk ścisłych, technicznych, przyrodniczych czy medycznych, którzy najwcześniej sięgnęli po wsparcie komputerowe $\mathrm{w}$ prowadzonych przez siebie projektach. W naukach społecznych i humanistycznych nowe technologie informatyczne zadomawiały się znacznie wolniej, stopniowo zyskując coraz szersze grono zwolenników. W przypadku socjologii w pierwszej kolejności dostrzeżono potencjał nowych technologii $\mathrm{w}$ badaniach prowadzonych przy użyciu metod ilościowych. Komputery wykorzystywane były do przetwarzania liczb oraz ilościowych analiz nienumerycznych, to jest frekwencyjnej analizy tekstów (Bieliński, Iwańska, Rosińska-Kordasiewicz 2007). Badacze jakościowi nie byli początkowo zainteresowani włączaniem nowych technologii do procesu badawczego, nie widzieli także możliwości ich zastosowania na etapie analizy danych. U podstaw takiego sposobu myślenia leżało między innymi pragnienie podkreślenia odrębnej tradycji i odmiennego sposobu prowadzenia analiz niż w badaniach ilościowych, gdzie nowe technologie komputerowe przyjęły się znacznie szybciej. Spory pomiędzy zwolennikami ilościowych i jakościowych metod badań społecznych na dłuższy czas odsunęły możli- wość powstania oprogramowania przeznaczonego specjalnie dla ,jjakościowców” i próbującego zaspokoić specyficzne potrzeby tego rodzaju analiz. Jednak stopniowo, w miarę dochodzenia do głosu kolejnych pokoleń badaczy jakościowych oraz tworzenia narzędzi, które mogły wspomagać proces analizy nieilościowej, komputery i specjalistyczne oprogramowanie zaczęły upowszechniać się w środowisku naukowym na tyle, że można już obecnie mówić o historii ich rozwoju i różnicowania się.

W historii oprogramowania wykorzystywanego w badaniach prowadzonych metodami jakościowymi można wyróżnić kilka kluczowych okresów, które wyznaczają kolejne etapy rozwoju tego typu narzędzi analizy danych. Jacek Bieliński, Katarzyna Iwańska, Anna Rosińska-Kordasiewicz (2007), a także Katarzyna Wilk (2001) wskazują na tak zwane generacje $\mathrm{w}$ rozwoju programów do analizy danych jakościowych:

- pierwsza generacja - obejmuje oprogramowanie stosowane $\mathrm{w}$ dziedzinach, w których występowały wyraźne procedury badawcze możliwe do przetworzenia w prosty sposób na algorytmiczne polecenia. Były to programy do ilościowej analizy zawartości tekstu, zawierające takie funkcje, jak: tworzenie alfabetycznych i frekwencyjnych list słów obecnych w tekście, wyszukiwanie słów w kontekście czy wyszukiwanie powtarzających się zbitek słownych. Były to zatem programy, które przede wszystkim operowały na poziomie statystycznej analizy słów;

Katedra Socjologii Organizacji i Zarządzania Instytut Socjologii UŁ

ul. Rewolucji 1905 r. 41, 90-214 Łódź e-mail: iza.slezak@gmail.com
- druga generacja - której okres przypada na lata osiemdziesiąte ubiegłego wieku - to programy należące do grupy tak zwanych code- 
and-retrieve programs, czyli programów nie tylko do wyszukiwania danych, ale również do ich kodowania (dwa najpopularniejsze z nich to Etnograph oraz NUD*IST);

- trzecia generacja programów zapoczątkowana została w latach dziewięćdziesiątych XX wieku. Rozwój oprogramowania polega w tym przypadku na udostępnieniu badaczowi narzędzi umożliwiających tworzenie powiązań między kodami, a w dalszej kolejności także konstruowanie teorii. Przykładami tego rodzaju oprogramowania są: NVivo, Atlas.ti czy MAXQDA (Bieliński i in. 2007; zob. Seale 2008).

Rozwój oprogramowania do analizy jakościowej wspomaganej komputerowo doprowadził więc do udoskonalenia i poszerzenia zakresu możliwości tego rodzaju narzędzi badawczych. Po pierwsze umożliwił wykorzystywanie coraz szerszej gamy źródeł danych nie tylko tekstowych, ale także zdjęć, obrazów i materiałów audiowizualnych. Po drugie rozwój oprogramowania zmierza $\mathrm{w}$ kierunku poszerzenia oferowanych funkcji i umożliwienia realizacji kolejnych, bardziej zaawansowanych etapów analizy danych (od prostego przeszukiwania i gromadzenia informacji do tworzenia teorii i wizualizacji modeli analitycznych). Po trzecie zaś, w kolejnych generacjach programów w coraz większym stopniu przywiązuje się uwagę do funkcjonalności, intuicyjności oraz prostoty posługiwania się programem przez potencjalnego użytkownika.

Wspomagana komputerowo analiza danych jakościowych (Computer-Assisted Qualitative Data Analysis Software [CAQDAS]) ma więc już swoją tradycję, a jej rozwój można rozpatrywać w dwóch aspektach: technologicznym oraz metodologiczno-analitycznym. Ten pierwszy odnosi się do technicznych możliwości nowoczesnych narzędzi informatycznych, a także konkretnych rozwiązań technologicznych zawartych w specjalistycznym oprogramowaniu komputerowym. Drugi aspekt dotyczy zaś dostosowywania oprogramowania do oczekiwań i wymagań badaczy oraz naukowców zajmujących się metodami jakościowymi. Z tego względu kryteriami oceny oprogramowania są między innymi: możliwość opracowywania różnorodnych danych, łatwość kodowania i tworzenia zależności między danymi, a także pomiędzy kodami oraz notatkami, czyli rodzaj funkcji dostępnych badaczowi. Przede wszystkim jednak dla potencjalnego użytkownika ważny jest stopień dopasowania konkretnego programu do przyjętego w projekcie podejścia badawczego (Saillard 2011).

Każdy program ma swoją charakterystykę i sposób organizowania poszczególnych działań w ramach procesu analitycznego. Co więcej, każdy z programów jest swoistym środowiskiem, w którym badacz pracuje i wykonuje określone czynności zgodnie z tak zwaną „architekturą oprogramowania", a więc technicznymi rozwiązaniami użytymi przez jego konstruktorów (Saillard 2011). Aktualnie dostępne programy są rezultatem współpracy wielu użytkowników, którzy pracując na danym oprogramowaniu, w praktyce sprawdzali jego możliwości i poprzez zgłaszanie autorom programu swoich opinii przyczyniali się do udoskonalania narzędzia. Należy jednak pamiętać, że język programowania oraz współczesna technologia narzucają określone ramy konstrukcyjne tego rodzaju na- rzędziom wspomagającym pracę badacza. Pomimo że CAQDAS oferują funkcje, które wspierają poszczególne etapy jakościowych projektów badawczych, architektura oprogramowania może mieć pewien wpływ na sposób prowadzenia analizy.

Z drugiej strony wydaje się, że idea przyświecająca producentom i twórcom oprogramowania jest to, aby programy wspomagające analizę jakościową nie nakładały żadnych ograniczeń natury metodologicznej i pozwalały badaczowi zastosować różne strategie analizy w zależności od jego potrzeb. W związku z tym bardzo trudno jest mówić o jednym, najlepszym programie czy wybrać ten najbardziej udany i przydatny $\mathrm{w}$ analizie zgromadzonych materiałów. Wiele zależy bowiem od tego, jakie są potrzeby danego badacza, jakich dokładnie metod używa, jakie problemy bada i jakie są jego osobiste preferencje naukowe. Każdy analityk powinien być świadom możliwości, ale i ograniczeń, jakie może nieść ze sobą zastosowanie komputerowego wspomagania analizy danych jakościowych w postaci konkretnego programu (Saillard 2011; Lonkila 1995). W artykule rozważamy kwestię tego, czy i w jakim zakresie nowoczesne oprogramowanie CAQDAS reprezentowane przez program NVivo $8^{1}$ wpływa na sposób organi-

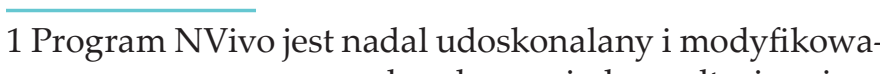
ny, w czym znaczącą rolę odgrywają konsultacje z jego użytkownikami z całego świata. 21 października 2010 roku miała miejsce kolejna odsłona oprogramowania, tym razem w wersji 9. W ten sposób firma QSR, wydawca $i$ dystrybutor programu wprowadzili na rynek wzbogacone narzędzie, rozwijające między innymi funkcje pracy zespołowej czy rozbudowanie możliwości posługiwania się arkuszami danych, a także oferujące jeszcze większą elastyczność poprzez rezygnację z narzucania badaczowi organizacji kategorii na bazie dostepnych $\mathrm{w}$ programie zainteresowanie oraz rozwój technologiczny będą sprzy- zowania i realizacji badań jakościowych prowadzonych zgodnie z procedurami teorii ugruntowanej (TU). Odpowiedzi na tak postawione pytania poszukujemy, bazując na osobistych doświadczeniach zdobytych podczas realizacji badań prowadzonych za pomocą metodologii teorii ugruntowanej oraz przy wykorzystywaniu programu NVivo w wersji 8 .

Metody jakościowe w naulkach społecznych

Metody badań jakościowych nieustannie się rozwijają. Jednakże historia ich ewolucji nie jest opowieścią o ujednolicaniu i rosnącej krystalizacji standardów metodologicznych, ale o różnicowaniu się podejść badawczych (Flick 2010). Jest to wynikiem odmiennych tradycji związanych ze sposobem rozumienia i uprawiania danego podejścia w konkretnych krajach (por. Knoblauch, Flick, Maeder 2005; Denzin, Lincoln 2009) czy dyscyplinach naukowych (socjologii, psychologii, pedagogice, antropologii itd.), w różnych obszarach badań (badania zlecone

jały pojawianiu się nowych wersji programu, czego zapowiedzią na początku 2012 roku była informacja na stronie producenta o następnej, 10 generacji oprogramowania, której wydanie ma nastąpić w połowie bieżącego roku. W związku z tym mamy świadomość, że opisane działanie programu w NVivo 8 będzie się różniło w stosunku do nowszych wydań, niemniej jednak najważniejsze funkcje programu, które de facto służą analizie jakościowej nie powinny ulegać znaczącym zmianom. Ewolucyjny rozwój programu sprawia, że istniejące rozwiązania są raczej rozwijane, a nie poddawane gruntownej zmianie i rekonstrukcji. Choć trudno jest orzekać o przyszłości i kierunkach rozwoju programu, mamy jednak nadzieję, że treści zwarte $\mathrm{w}$ artykule, zwłaszcza $\mathrm{w}$ zakresie dotyczącym dyskusji nad użytecznością programu wspierającego badacza $\mathrm{w}$ analizie zgodnej $\mathrm{z}$ procedurami metodologii teorii ugruntowanej, pozostaną aktualne. Zachęcamy także do osobistego zapoznania się z bieżąca, pełną 30-dniową wersja programu udostępnioną
http://www.qsrinternational.com 
i marketingowe, akademickie, podstawowe) czy wreszcie współwystępowania w ramach podejścia jakościowego programów badawczych o odmiennych założeniach (np. metodologia teorii ugruntowanej i analiza dyskursu) (Flick 2010). Trudno jest zatem sformułować jedną definicję, która oddawałaby wielość podejść zawierających się we wspólnej rodzinie metod badań jakościowych. W jej ramach można jednak wyróżnić kilka perspektyw badawczych charakteryzujących główne sposoby rozumienia i uprawiania metod jakościowych (Flick 2010):

- oparte na punkcie widzenia badanych, dla których teoretycznym punktem odniesienia jest tradycja interakcjonizmu symbolicznego oraz fenomenologii. Zadaniem jakie owe podejścia stawiają przed metodami jakościowymi jest próba spojrzenia na rzeczywistość z perspektywy badanych podmiotów, a więc odkrycie punktu widzenia członków danej zbiorowości;

- opierające się na opisach konstruowania sytuacji społecznych - są teoretycznie zakorzenione w etnometodologii i konstrukcjonizmie. Celem tych opisów ma być przedstawienie procesów związanych ze społecznym wytwarzaniem istniejących sytuacji, środowisk i ładu społecznego;

- dotyczące hermeneutycznej analizy głębokich struktur - opierające się na stanowisku strukturalistycznym i psychoanalitycznym. W tym podejściu, zakładającym istnienie nieświadomych struktur i mechanizmów psychiki, dąży się do rekonstrukcji głębokich struktur leżących u podłoża działania i znaczenia.
Poszczególne perspektywy różnią się pod względem celów, jakie stawiane są badaniom oraz sposobów ich realizacji, a więc wykorzystywanych $\mathrm{w}$ ich ramach metod i technik gromadzenia danych oraz strategii analizy. Termin badania jakościowe jest więc pojemną kategorią obejmującą swym zakresem szereg podejść badawczych w naukach społecznych (Flick 2010). Z tego względu potrzeby badaczy, którzy wykorzystują $\mathrm{w}$ swoich analizach odmienne metody $\mathrm{z}$ rodziny jakościowych mogą się od siebie znacząco różnić. Taka sytuacja - w połączeniu z ograniczeniami technologicznymi - nie sprzyjała szybkiemu pojawieniu się rozbudowanych narzędzi komputerowego wspomagania analizy jakościowej. Zwłaszcza zaś wykształceniu się takich programów, które byłyby w stanie obsługiwać różne rodzaje analizy i spełniać oczekiwania wszystkich badaczy.

W niniejszym artykule koncentrować się będziemy przede wszystkim na metodologii teorii ugruntowanej². Na jej powstanie ogromny wpływ miały dyskusje toczone w połowie ubiegłego wieku, związane między innymi $\mathrm{z}$ falą krytyki badań ilościowych, zwłaszcza zaś uprawiania nauki zza biurka. $W$ tym kontekście ważnym głosem była praca Barneya G. Glasera i Anselma L. Straussa pod tytułem The discovery of

2 Należy zaznaczyć, że tak jak metody jakościowe rozwijają się w wielu różnych kierunkach, tak i metodologia teorii ugruntowanej nie jest jednolitym podejściem ba dawczym. Można wyrożnic tak zwaną klasyczną teorie ugruntowaną (Glaser, Strauss 1967), teorię ugruntowana rozwijaną przez B. Glasera, a później także Judith Holton (Glaser, Holton 2004), teorię ugruntowaną Straussa i Juliet Corbin (199), konstruktywistyczną teorię ugruntowan (Charmaz 2009), analizę sytuacyjną Adeli Clarke (2005). rozwi janie szczegolowych kwestii związanych z róznniejszego tekstu. grounded theory. Strategies for qualititive research ${ }^{3}$, która wprowadzała metodologię odmienną od dotychczas stosowanych $\mathrm{w}$ naukach społecznych. W opinii jej twórców metodologia teorii ugruntowanej oferowała nową perspektywę uprawiania nauki, przeciwstawiając się teoriom ustanawianym w sposób logiczno-dedukcyjny, opartym na weryfikacji arbitralnie stawianych założeń i hipotez (Glaser 1978). Zdaniem Glasera i Straussa teoria ugruntowana miała wypełnić lukę pomiędzy teorią a empirią (Glaser, Strauss 1967; Strauss, Corbin 1990; Konecki 2000; Gorzko 2008; Charmaz 2009).

Zaproponowana strategia polega na budowaniu teorii (średniego zasięgu) w oparciu o systematycznie gromadzone dane empiryczne (Glaser, Strauss 1967; Glaser 1978). Teoria jest więc pochodną analiz danych empirycznych i wyłania się $\mathrm{w}$ trakcie systematycznie prowadzonych badań terenowych z danych, które bezpośrednio odnoszą się do obserwowanej części rzeczywistości społecznej. Hipotezy, pojęcia i własności pojęć są budowane, modyfikowane i weryfikowane $\mathrm{w}$ trakcie badań empirycznych. Tak więc budowanie teorii jest ściśle powiązane z długotrwałym procesem badawczym (Konecki 2000). Można powiedzieć, że celem badacza jest stopniowe przechodzenie od materiału empirycznego na coraz wyższe poziomy abstrakcyjnego rozumowania poprzez tworzenie zróżnicowanych hierarchicznie kategorii i ich własności - aż do konstruowania hipotez i teorii. Logika procesu

3 Metody jakościowe nie stanowią jednolitego zbioru wytycznych, zaś na ich rozwój wpływały także prace innych badaczy reprezentujących różne nurty badań uprawianych $w$ ramach paradygmatu jakościowego. Niemnie jednak ze względu na charakter i problematykę artykuugruntowanej oraz jej czołowych przedstawicieli. badawczego opiera się na dążeniu do coraz wyższego poziomu konceptualnego, a co za tym idzie - oderwania się od danych ku teoretyzowaniu. Kluczową rolę odgrywa w tym kontekście proces kodowania, a więc przypisywania partiom materiału określonych etykiet odzwierciedlających ich sens i znaczenie nadawane im przez aktorów społecznych i odwzorowane przez badacza. Działaniom tym towarzyszą określone procedury metodologicznej poprawności, do których w przypadku TU należą między innymi teoretyczne pobieranie próbek (theoretical sampling), procedura ciągłego porównywania (constant comparative metod), kodowania, pisania not. Proces zbierania danych empirycznych odbywa się w przypadku stosowania TU nie stadialnie, fazowo, lecz naprzemiennie z prowadzoną równolegle analizą i interpretacją.

Ponieważ każda z metod jakościowych wymaga określonych procedur analitycznej poprawności, będących swego rodzaju instrukcjami, według których powinien postępować badacz-analityk, powstaje pytanie o możliwość zastosowania owych procedur w przypadku, gdy badacz posługuje się specjalistycznym oprogramowaniem komputerowym. Bowiem chociaż programy CAQDAS są coraz doskonalszym narzędziem wspomagającym pracę badacza, ich wewnętrzna architektura nadal podporządkowana jest wymogom i możliwościom współczesnej technologii. Dlatego dyskusję o użyteczności oprogramowania do wspomagania analizy jakościowej rozpocząć należy od możliwości jego zastosowania do konkretnej perspektywy metodologicznej (Schönfelder 2011).

Nim przejdziemy do omówienia kwestii porównania wymogów TU (jako reprezentującej me- 
tody jakościowe) z możliwościami, jakie oferuje oprogramowanie komputerowe, postaramy się wyjaśnić pokrótce specyfikę działania tego rodzaju oprogramowania, biorąc za przykład program NVivo.

Charakterystyka oprogramowania NVivo jako przykładu programu CAQDAS

Historia oprogramowania NVivo sięga począt$\mathrm{ku}$ lat osiemdziesiątych $\mathrm{XX}$ wieku $\mathrm{u}^{4}$. Od tamtej pory przeszło ono liczne zmiany i modyfikacje, które doprowadziły do wykształcenia się wersji współczesnych (mamy na myśli wersje programu NVivo od 7 do 9). Obecnie program NVivo oferuje bardzo wiele rozbudowanych funkcji pozwalających na wykonywanie zaawansowanych analiz jakościowych, począwszy od prostego grupowania i zliczania danych po tworzenie hipotez i generowanie teorii. NVivo uważany jest za narzędzie wspomagające projekty badawcze z zakresu analizy dyskursu, metodologii teorii ugruntowanej, analizy konwersacyjnej, etnografii, badań opartych na fenomenologii, a także innych, w tym mieszanych metod badawczych (Schönfelder 2011). Poniżej pragniemy przedstawić najważniejsze funkcje, jakie udostępnia program NVivo, ze wskazaniem ich przydatności $\mathrm{w}$ procesie analizy jakościowej zgodnej z metodologią teorii ugruntowanej.

4 Wersjami programu poprzedzającymi pojawienie się NVivo był NUD*IST (Non-Numerical Unstructured Data Indexing Searching and Theorizing), a nastepnie oprogramowanie noszące nazwę QSR - od wersji N4 do N6. Ta ostatnia dała poczatek linii oprogramowania NVivo (więcej informacji na ten temat można znaleźc na stronie internetowej $h$ htp://www.qsrinternational.com/about-qsr hi-
story.aspx).

\section{Sposób organizacji danych $\mathbf{w}$ programie} NVivo 8

Jedną z podstawowych funkcji oprogramowania CAQDAS jest porząd kowanie wszelkich materiałów importowanych do projektu oraz będących wytworami pracy analityka. Należy zauważyć, że każdy rodzaj oprogramowania reprezentuje pewien określony sposób segregowania informacji. Zgodnie z wewnętrzną logiką programu NVivo dane importowane (m.in. wszelkiego rodzaju materiały źródłowe) oraz wytworzone przez badacza bezpośrednio $\mathrm{w}$ programie (np. memo) mogą zostać pogrupowane i w odpowiedni sposób posegregowane. Dzięki temu uzyskujemy możliwość panowania nawet nad bardzo rozbudowaną bazą danych.

Podstawową formą segregowania danych jest tworzenie zbiorów dokumentów (Sets), które pozwalają miedzy innymi na tematyczne grupowanie materiałów, zgodnie $\mathrm{z}$ założeniami analitycznymi i potrzebami badacza. Drugi sposób to operowanie pojedynczymi dokumentami źródłowymi (Source). W tym przypadku badacz może uporządkować dane importowane (Internals) do bazy danych bądź z nią zlinkowane (Externas), tworząc katalogi reprezentujące określone rodzaje wykorzystywanych $\mathrm{w}$ badaniu materiałów (np. wywiady, zdjęcia, audio, wideo). Trzecia możliwość dotyczy tak zwanych przypadków (Cases), które mogą służyć jako reprezentacja poszczególnych osób bądź organizacji stanowiących przedmiot zainteresowań badawczych. Dodatkowo, wykorzystanie opcji Attributes pozwala na przypisanie własności danych metryczkowych określonym przypadkom. Ponieważ zaś głównym zadaniem badacza jest praca z materiałem, a więc jego kodowanie, tworzenie kategorii i szukanie powiązań między nimi, program NVivo także w tym zakresie pozwala na porządkowanie procesu analitycznego poprzez wykorzystanie opcji grupowania kategorii w złożone struktury, czego podstawę stanowi drzewo kategorii (Tree Nodes). $\mathrm{Na}$ najwyższym poziomie konceptualnym badacz dąży do wygenerowania określonych powiązań i odkrycia związków między kategoriami, w czym ważną rolę odgrywają noty teoretyczne. W programie NVivo rolę not teoretycznych pełnią memos, a więc zapisy myśli teoretycznych i koncepcji badacza. Również w tym przypadku badacz zyskuje możliwość porządkowania tak utworzonych danych i nadawania im określonej struktury, na przykład katalogując memos oraz opatrując je datą utworzenia w celu śledzenia zmian $\mathrm{w}$ procesie analizy $\mathrm{i}$ interpretacji danych.

\section{Obszar roboczy i interfejs}

Wspomniana powyżej struktura grupowania danych ma swoje odzwierciedlenie w układzie interfejsu programu. Po uruchomieniu NVivo wydaje się on podobny do większości innych programów opartych na MS Windows, co wynika z faktu, że NVivo jest przystosowany do pracy w środowisku Microsoft. Menu główne i paski narzędzi znajdują się w górnym oknie, a poszczególne funkcje do wykonywania zadań analitycznych są dostępne za pośrednictwem głównego menu lub ikon skrótu na pasku narzędzi (Schönfelder 2011).

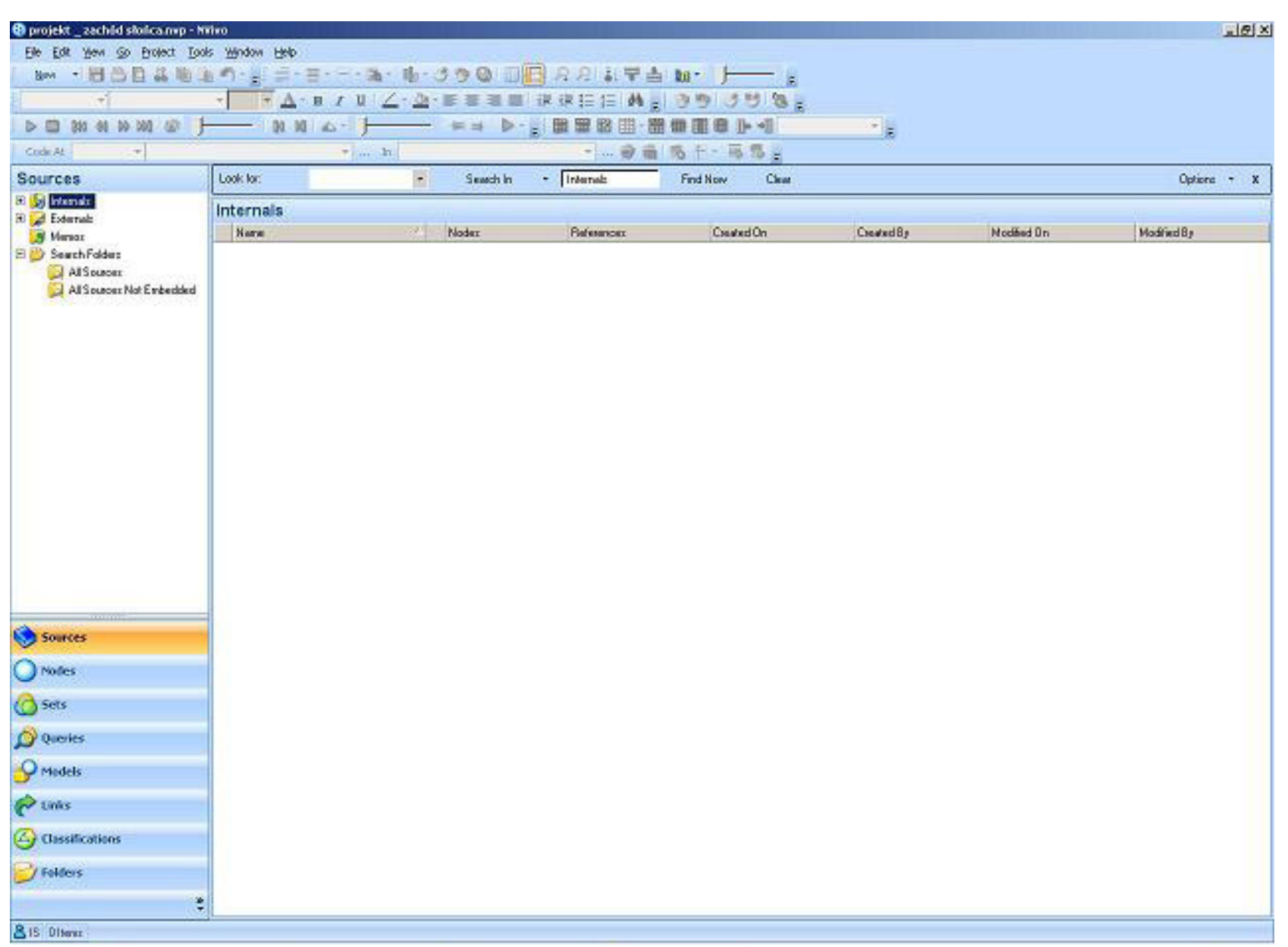

Rys. 1. Wygląd głównego okna programu NVivo 8 


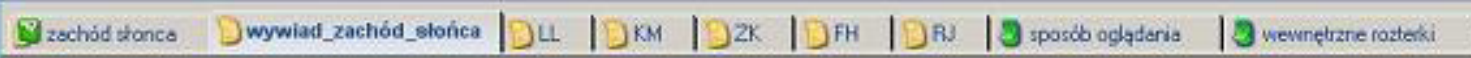

Rys. 2. Obszar roboczy programu NVivo z otwartymi plikami

Po uruchomieniu programu i wpisaniu informacji o użytkowniku (jego inicjałów) oraz wybraniu projektu, ukazuje się główny interfejs programu. W NVivo jest on podzielony na kilka głównych obszarów. W górnej części okna znajduje się rozwijane menu oraz paski narzędzi (które można dowolnie modyfikować, dodając do nich poszczególne funkcje bądź je usuwając). Nieco poniżej istnieje możliwość włączenia paska przeszukiwarki, dzięki której użytkownik może wyszukiwać dane ze wszystkich dostępnych źródeł i materiałów znajdujących się w bazie danych. Drugi obszar to menu nawigacji zajmujące lewą część okna interfejsu. Jego dolna część zawiera główne zbiory danych, do których należą kolejno: Sources (źródła), Nodes (kategorie, węzły), Sets (zbiory), Queries (zapytania), Models (modele), Links (linki), Classification (klasyfikowanie). Powyżej znajduje się przestrzeń, w której wyświetlane są dane i materiały stanowiące zawartość jednego z wymienionych wcześniej elementów menu. Zdecydowanie największą przestrzeń interfejsu zajmuje okno robocze, w którym wyświetlane są elementy projektu wybrane przez użytkownika. Istnieje możliwość otwarcia kilku plików jednocześnie, a ułatwieniem w przeglądaniu każdego z nich jest system zakładek, dzięki którym można bez problemu poruszać się w obrębie interesujących użytkowania materiałów i danych.

Program NVivo posiada swoisty system nazewnictwa. Uwage zwraca przede wszystkim zmiana terminów - „kody” w NVivo funkcjonują pod nazwą "węzły" (Nodes). Dla początkujących użytkowników ta odmienność idiosynkratyczna języka może być nieco problematyczna. Przy czym powód odstępstwa od ustalonych i tradycyjnie funkcjonujących terminów nie jest przekonująco wyjaśniony przez wydawcę oprogramowania. Niemniej jednak nie jest to duża wada narzędzia, choć wymaga od użytkownika pewnego przyzwyczajenia (Schönfelder 2011).

\section{Regulacja i ergonomia pracy - dostosowanie} programu do potrzeb użytkownika

Jak zaznaczyliśmy powyżej, badania jakościowe charakteryzują się silnym zróżnicowaniem, co skutkuje stosowaniem $\mathrm{w}$ ich obrębie różnych metod i sposobów prowadzenia analizy. Przekłada się to także bezpośrednio na osobisty styl pracy badacza. Aby wyjść naprzeciw różnym potrzebom, dobrze zaprojektowany pakiet CAQDAS powinien zapewnić możliwość dostosowania obszaru roboczego do osobistych preferencji użytkownika. W programie NVivo jest to osiągnięte między innymi poprzez możliwość zastosowania oprogramowania do projektów wykonywanych w duchu różnych metod jakościowych. Taka elastyczność jest wynikiem prób sprostania przez producentów programu oczekiwaniom użytkowników reprezentujących różne szkoły i posługujących się odmiennymi metodami (NVivo to bowiem program należący do rodziny oprogramowania uniwersalnego, a więc skonstruowanego dla różnych badań, projektowanych z zastosowaniem rozmaitych metod). Jednocześnie twórcy programu wychodzą naprzeciw różnorodnym przyzwyczajeniom anali- tyków - jako zwykłych użytkowników komputera - którzy mają swoje nawyki dotyczące sposobów obsługi sprzętu i posługiwania się oprogramowaniem. NVivo pozwala między innymi pokazywać, ukrywać i przenosić paski narzędzi na ekranie. Istnieje także możliwość użycia określonych funkcji z poziomu rozwijanego menu bądź ikonek znajdujących się na pasku menu oraz za pomocą kombinacji skrótów klawiszowych (Schönfelder 2011; Saillard 2011). W efekcie program oferuje dużą dowolność w kreowaniu przestrzeni roboczej i dostosowaniu jej do indywidualnych potrzeb użytkownika.

Funkcje NVivo 8 wspomagające proces analizy jakościowej

\section{Segregacja, porządkowanie i przeszukiwanie} zebranego materiału

Badacze jakościowi, w zależności od reprezentowanego nurtu badań i stosowanej metodologii, posługują się $\mathrm{w}$ swoich analizach różnymi rodzajami danych. Twórcy programu NVivo dążąc do tego, by był on dostosowany do jak najszerszego grona odbiorców, pragnęli sprostać temu wyzwaniu, co stało się możliwe stosunkowo niedawno, gdy rozwiązano stojące przed projektantami problemy natury technicznej. Począwszy od wersji 7, program NVivo oferuje możliwość wykorzystania $\mathrm{w}$ analizie materiałów bardzo różnego rodzaju. Oprócz tekstu są to zdjęcia, materiały audio i wideo, a także dane pochodzące z innych rodzajów źródeł, jak na przykład witryn internetowych.

Najnowsze narzędzia z rodziny CAQDAS pozwalają na importowanie do bazy danych programu materiałów źródłowych (nagrania audio i wideo, materiały tekstowe) bez utraty formatowania, a także w postaci zapisanej w różnych rodzajach formatów (m.in. rozszerzenia .txt, .doc, .docx, .pdf). NVivo umożliwia również tworzenie transkrypcji i opisów plików audio-wideo. Takie zapisy mogą być kodowane oraz opatrywane uwagami, tworząc odrębne elementy projektu, przy jednoczesnym zachowaniu linku do pierwotnych plików audio i wideo (Schönfelder 2011). Pliki mogą być zamieszczone bezpośrednio w bazie danych programu, jeśli ich wielkość nie przekracza $40 \mathrm{MB}$. Nie oznacza to jednak, że materiały o większej objętości nie mogą być wykorzystywane $\mathrm{w}$ projekcie. Jednak formalnie pozostają one poza bazą danych, są natomiast połączone z projektem za pomocą systemu linków i odsyłaczy do danego pliku.

Program NVivo umożliwia porządkowanie zaimportowanych danych zamieszczanych w katalogu źródeł wewnętrznych (Internals). W jego ramach użytkownik może w sposób dowolny segregować materiały, tworząc system katalogów zgodnie ze swoimi potrzebami. Mogą one zawierać na przykład dane wydzielone ze względu na technikę ich pozyskania (audio, wideo, wywiady, obserwacje). Ponadto program NVivo pozwala na korzystanie $\mathrm{z}$ danych, których nie można bezpośrednio importować do bazy danych, na przykład ze względu na ich specyfike (tak jak ma to miejsce $\mathrm{w}$ przypadku stron i witryn internetowych). Takie dane źródłowe są przechowywane w postaci linków i hiperłączy w specjalnie do tego celu przeznaczonym folderze źródeł zewnętrznych (Externals).

Badacz wyposażony zostaje także w rozbudowane narzędzie do przeszukiwania danych, które pozwala na wyszukanie interesujących go frag- 


\begin{tabular}{|c|c|c|c|c|c|}
\hline Sources & Look for: & - & Seachin & - Irídła zewnętzan & Find $N$ \\
\hline QD. Internals & \multicolumn{5}{|c|}{ żródla zewnętrzne } \\
\hline 3 wywiady & Name & Nodes & & References & \\
\hline adieccia & st stona now & 1 & & 1 & \\
\hline Q E Exemals & fe wywiad sudio & 0 & & 0 & \\
\hline (1) zoda zemnerrane & 6 plk video & 0 & & 0 & \\
\hline
\end{tabular}

(9) Mernos

Rys. 3. Folder zewnętrznych materiałów źródłowych (Externals)

mentów i określonych segmentów materiałów. W ten sposób uzyskuje się możliwość szybkiego dostępu do poszczególnych plików, które zawierają poszukiwane przez badacza informacje.

Możliwości jakie w zakresie gromadzenia materiałów daje program NVivo, pozwalają badaczowi panować nad znacznymi nawet ilościami danych. Wykorzystując funkcje porządkowania oraz wyszukiwania, użytkownik może bez większego problemu dotrzeć do ważnych dla niego informacji szybko i bez trudności, jakie towarzyszyły badaczom organizującym swoje badania w sposób tradycyjny, a więc z wykorzystaniem papierowych zbiorów danych i katalogów. Z tej perspektywy narzędzie informatyzujące materiały wydaje się być niezwykle przydatne badaczowi, tworzac środowisko przyjazne analizie. Te udogodnienia, w połączeniu z możliwościami tworzenia obszernej bazy danych składającej się z różnych rodzajów materiałów empirycznych, dają najlepszy wyraz temu z jak złożonym i zaawansowanym technicznie narzędziem mamy do czynienia. Niemniej jednak możliwości programu NVivo wychodzą daleko poza wspomniane tutaj funkcje i dotyczą wspierania procesu analizy danych jakościowych w jego kolejnych, coraz bardziej zaawansowanych etapach.
System notatek $\mathrm{i}$ adnotacji $\mathrm{w}$ programie NVivo

Kolejną bardzo przydatną funkcją, jaką oferuje program NVivo jest możliwość tworzenia notatek i adnotacji, które pozwalają na zapisanie myśli badacza oraz rozwinięcie treści zawartych w kodach. Takie postępowanie jest zresztą zgodne z założeniami badań jakościowych projektowanych i prowadzonych zgodnie z metodologia teorii ugruntowanej. Pisanie not teoretycznych i metodologicznych (memos) towarzyszy analitykowi niemal od początku procesu badawczego (Konecki 2000). W metodologii jakościowej formą notatek są wszelkiego rodzaju zapiski sporządzone przez naukowca podczas całego procesu badawczego. Mogą one dotyczyć całego projektu, zebranych danych w ogóle lub każdego źródła danych z osobna, a także kolejnych etapów analizy oraz poszczególnych kodów (Saillard 2011).

Sporządzanie notatek ma kluczowe znaczenie na każdym poziomie procesu kodowania i analizy danych (por. Strauss, Corbin 1990). Innymi słowy, począwszy od kodowania otwartego badacz powinien, o ile to możliwe, zapisywać wszystkie rodzące się w jego głowie pomysły dotyczące interpretacji danych i wyciągania wniosków z analizy. W tym kontekście narzędzia, takie jak na przykład komentarze, notatki lub adnotacje - oferowane przez pakiety CAQDAS - zyskuja istotne znaczenie dla podejścia jakościowego, umożliwiając prowadzenie analiz z wykorzystaniem TU. Dlatego też Elif Kuş Saillard sugeruje, aby nazywać je „narzędziami refleksji” badacza (2011). Z tej perspektywy wydaje się, że jedną z najbardziej atrakcyjnych cech oprogramowania komputerowego CAQDAS jest możliwość opisywania dokumentów analitycznych (Schönfelder 2011).

Program NVivo wyposażony jest $\mathrm{w}$ funkcjonalny i prosty w użyciu edytor tekstu, pozwalający na swobodne zapisywanie pomysłów i spostrzeżeń badacza. W programie NVivo wszystkie opcje dotyczące tworzenia notatek dostępne są za pośrednictwem opcji Links w menu głównym lub mogą być wywołane podczas pracy $\mathrm{w}$ otwartym dokumencie przez kliknięcie prawym przyciskiem myszy (Schönfelder 2011).

Trzeba przy tym rozróżnić dostępne $\mathrm{w}$ ramach czynności „notatkowania” (Memoring) szczegółowe funkcje dostępne w programie NVivo. Należą do nich noty (Memos) oraz adnotacje (Annotations).

\section{A. Notatki w NVivo - tworzenie memos}

Memos to zwięzłe notatki badacza, zwierające informacje o pomysłach dotyczących całego projektu, konkretnych materiałów bądź też kwestii do dyskusji lub przyszłej interpretacji. Idea memos w programie NVivo jest analogiczna do procedury tworzenia not $\mathrm{w}$ TU. Mają one pomóc badaczowi przejść na wyższy poziom konceptualny i jako narzędzia kodowania teoretycznego służą generowaniu teorii (Konecki 2000). Two- rząc notatki teoretyczne $\mathrm{w}$ programie NVivo, badacz może je modyfikować na każdym etapie procesu analizy stosownie do jej postępów. Wszystkie memos - z uwagi na ich ważną rolę $\mathrm{w}$ procesie analizy - są wydzielone w odrębną kategorię dostępną w menu Source (źródła). Co więcej, stworzone notatki mogą stanowić odrębne dokumenty, w których badacz rejestruje swoje własne myśli i działania w ramach danego projektu (Wiltshier 2011).

Utworzenie memo polega na wybraniu odpowiedniej opcji na przykład z menu New. W ten sposób można swobodnie tworzyć teoretyczne adnotacje oraz interpretacje odnoszące się do fragmentów danych. Istnieje także możliwość zapisywania swobodnych myśli badacza, które następnie można połączyć z wybranym fragmentem materiału źródłowego bądź kodem. Możliwe jest także tworzenie memos od razu połączonych z daną partią materiału źródłowego - poprzez wybranie opcji Link To New Memo z menu Links. Warto wspomnieć, że wszystkie memos są dostępne w menu Sources w katalogu Memos ${ }^{5}$.

Memos można także kodować, by uwypuklić istotne dane, które są $\mathrm{w}$ nich zawarte lub też w celu skupienia się na nowych wątkach bądź pytaniach, które pojawiły się $\mathrm{w}$ trakcie prowadzonej analizy. Oczywiście można również usunąć memo bądź link do memo z materiałem bądź określonym źródłem. Należy jednak pamiętać, że usunięcie linku nie powoduje automatycznej likwacji samego memo.

5 Do istniejących już memo można także dodać informację o czasie i dacie ich powstania, dzięki czemu łatwiej jest śledzić progresję procesu analizy. W tym celu należy $\mathrm{z}$ menu Format wybrać funkcję Insert, a następnie wybrać funkcję Data/Time. 


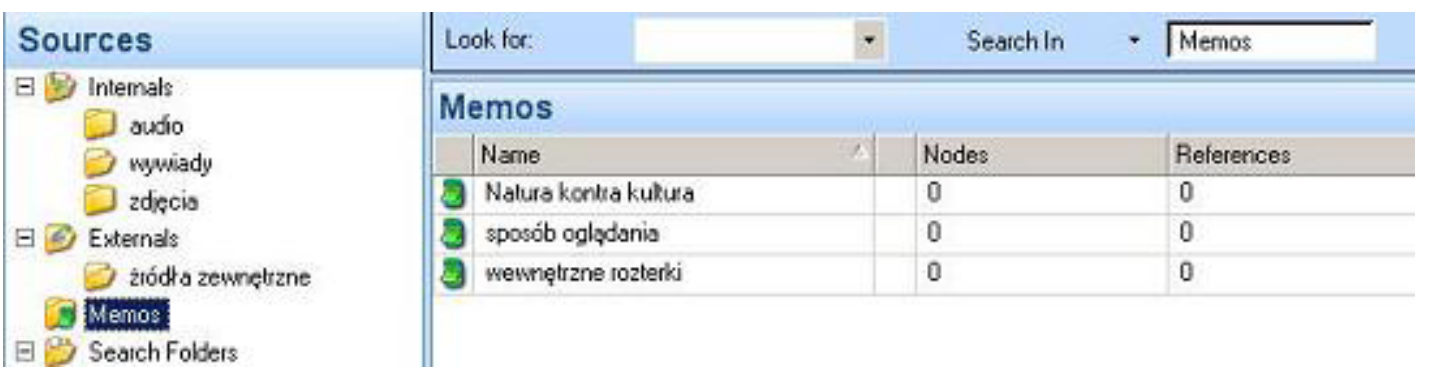

Rys. 4. Memo w programie NVivo

W NVivo Memos otwieramy w nowej karcie $\mathrm{w}$ oknie widoku $\mathrm{w}$ obszarze roboczym. $\mathrm{W}$ ten sposób można przechodzić między źródłem danych i notatką. Jednym minusem sposobu zaprojektowania funkcji tworzenia memo jest to, że odpowiednie dane i notatki nie pojawią się jednocześnie bez konieczności przechodzenia pomiędzy zakładkami głównego interfejsu (Saillard 2011).

W NVivo memo można połączyć ze źródłem danych lub wybranym kodem (węzłem). Memos w programie NVivo są traktowane jako odrębne elementy projektu, które mogą podlegać przeszukiwaniu, łączeniu z innymi elementami a także kodowaniu. Notatka w tej formie nie może jednak funkcjonować jako drobna notka dotycząca wybranych segmentów źródła danych lub kodowanych treści i do nich przypisana. Zamiast tego NVivo oferuje narzędzie adnotacji, które odpowiada krótkiej notatce na marginesie kartki, będącej uwagą do danej sekcji czy partii materiału.

\section{B. Adnotacje w NVivo}

Jeśli badacz chce dołączyć informację odnoszącą się tylko do określonego segmentu danych,

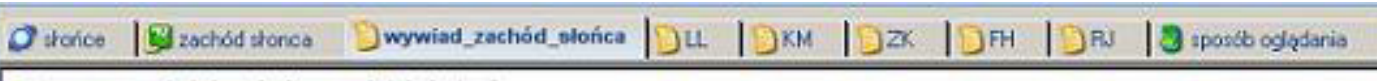

\section{Pyttasz, co czujejakk ogladam zachód slonica?}

Powiem ci ze czuję i to czuję bardzo wiele (pauza).

Uwielbiam patrzec na zachod stonca. To spravia mi wiella przyemnose kiedy moge tak staci sie

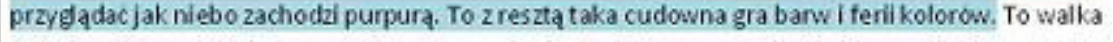

swiattla z ciemnoscią, Itocrą musi ono przegraci. Ale to ric straconego (smiech), przeciezjutro tezjest

koljejny dzien inastepny zachod stonca. 2 nieciempliwoscia czekam na kazdy zachod stonca.

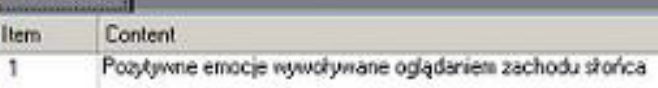

Rys. 5. System adnotacji w programie NVivo może utworzyć link do notatek zwanych adnotacjami (Annotation). Adnotacja pojawi się jako przypis na końcu źródła danych lub kodu (Saillard 2011).

W przeciwieństwie do not (memos) adnotacje nie są osobnym elementem projektu, ale pozostają osadzone w źródle (pliku), podobnie jak komentarze $\mathrm{w}$ dokumencie programu MS Word. Zawartość adnotacji może być uwzględniona $\mathrm{w}$ wyszukiwaniu, ale w przeciwieństwie do treści notatek nie może być ona kodowana (Schönfelder 2011).

Adnotacje można porównać do karteczek przyklejonych na marginesie albo podkreśleń $\mathrm{w}$ tekście, używanych w celu oznaczenia jakiegoś istotnego fragmentu danych. Można je wykorzystać dla opatrzenia fragmentu materiału krótką informacją lub zanotowania czegoś w celu sprawdzania przez badacza danej kwestii później (na przykład, gdy dostępne będą dane umożliwiające wyjaśnienie określonych kwestii).

Aby użyć funkcji adnotacji, należy zaznaczyć wybrany fragment danych źródłowych, a następnie wybrać z menu Links opcję New Annotation (lub prawym przyciskiem myszy otworzyć menu kontekstowe i wybrać odpowiednią opcję). Po wywołaniu tej funkcji poniżej tekstu źródłowego pojawia się okno do wpisania adnotacji. Od tej pory fragment tekstu z przypisaną adnotacją zostaje oznaczony (zakreślony) kolorem niebieskim. Adnotacje mogą być także zastosowane $\mathrm{w}$ materiałach wizualnych, na przykład wideo. Umieszczenie adnotacji odbywa się na dwa sposoby. Po pierwsze można oznaczyć fragment transkrypcji w sposób analogiczny jak ma to miejsce w przypadku źródeł tekstowych bądź
- w drugim przypadku - zaznaczyć fragment na linii czasu (Timeline), będącej ścieżką zapisu audio-wideo nagranego pliku. Wówczas reprezentacją adnotacji będzie niebieska kreska powyżej danego fragmentu linii czasu. Z kolei fotografię można oznaczyć partiami, wybierając jej fragment, który zostaje podświetlony niebieskim odcieniem, wyróżniającym się na tle całego zdjęcia. Wszelkie adnotacje można wywołać za pomoca opcji głównego menu bądź odpowiedniej ikonki na panelu. Aby przeczytać, co jest napisane w adnotacji, można kliknąć na przycisk Annotation View, który jest dostępny na pasku narzędzi (Saillard 2011).

Wskazane wyżej narzędzia opracowywania not i adnotacji oferowane przez NVivo znajdują zastosowanie zarówno w przypadku projektów badawczych opartych o zasady metodologii teorii ugruntowanej, jak i innych z zakresu metod jakościowych.

Funkcja not i adnotacji w NVivo daje badaczowi możliwość utrwalania swoich pomysłów analitycznych, ich systematycznego rozwijania, wzbogacania, modyfikowania, a więc jednocześnie prowadzenia pracy analitycznej oraz jej kontroli. Nawet luźne uwagi (ulotne pomysły) mogą mieć wpływ na analizę i interpretację, a także na porównanie danych $\mathrm{w}$ procesie ich przeglądania (Wiltshier 2011).

Każdy z opisanych rodzajów narzędzi notatkowych wpisuje się w ramy TU, wspomagając proces analizy. Adnotacje najlepiej sprawdzają się jako drobne zapiski, w których badacz umieszcza swoje pomysły i luźne myśli. Natomiast memos, ze względu na fakt, że mogą być kodowane, stanowią ciekawe rozwiązanie dla tworzenia 
not teoretycznych i przenoszenia analitycznych myśli badacza na wyższy poziom konceptualny.

\section{Tworzenie powiązań pomiędzy elementami projektu}

Narzędziem dostępnym w programie NVivo, należącym do rodziny funkcji linkowania, jest See Also Links. Dzięki temu narzędziu do określonego segmentu danych możemy wstawić link łączący go z innym źródłem lub jakimkolwiek innym elementem projektu. Funkcji tej można użyć na przykład dla połączenia transkrypcji danych z ich materiałem źródłowym i to nawet w przypadku, gdy materiał ten jest niezaimportowany do bazy programu, lecz stanowi dane zewnętrzne (Externals). W tym celu należy najpierw zaznaczyć fragment tekstu, a następnie z menu Links wybrać opcję See Also Links i dalej New See Also Links. Dalej należy wybrać określony materiał źródłowy i zaakceptować wybór. Panel See Also Links otworzy się automatycznie, zaś fragment zlinkowanego tekstu będzie zakreślony na czerwono. W przypadku materiałów audio i wideo należy zaznaczyć dany fragment na linii czasu, co spowoduje pojawienie się powyżej niej czerwonego paska symbolizującego wykorzystanie opcji See Also Links. Zaś w odniesieniu do zdjęć należy zaznaczyć określony

obszar, co powoduje zmianę koloru zakreślonego w ten sposób fragmentu. Możemy również wykorzystać opisy powyższych rodzajów materiałów źródłowych i za pomocą funkcji See Also Links zlinkować je z określoną partią innego materiału. Poza tym See Also Links nie podlega wielu ograniczeniom, jakie istnieją w przypadku Memo, można więc tutaj stworzyć wiele linków łączących poszczególne memos oraz źródła danych. Funkcji See Also Links możemy także użyć do połączenia fragmentów pochodzących z różnych materiałów źródłowych. W tym celu należy zaznaczyć interesujący badacza fragment tekstu, transkrypcji, obszaru zdjęcia bądź odcinka na linii czasu, a następnie wybrać z menu kontekstowego (otwieranego prawym przyciskiem myszy) opcję Copy. Następną czynnością jest zaznaczenie określonej porcji danych, na przykład fragmentu innego wywiadu i wybór z menu kontekstowego opcji Paste As See Also Links (Saillard 2011). Wszystkie wykonane przez badacza połączenia można przeglądać korzystając z opcji See Also Links w menu nawigacji Links.

Warto dodać, że funkcję linkowania reprezentują także inne narzędzia poza See Also Links. Przykładem może być tutaj funkcja Relationship, która służy do tworzenia połączeń pomiędzy różnymi elementami projektu: kodami (Nodes) i katego-

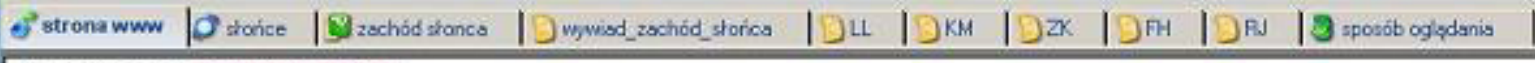

ta strona jest o zachodzie storical
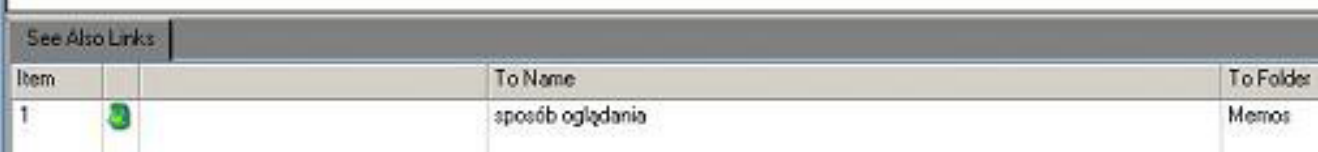

Rys. 6. Zestawienie powiązanych materiałów za pomocą funkcji See Also Links riami, a także danymi przypadkami. Posługując się tą funkcją, można określić rodzaj relacji oraz to, czy jest ona jedno czy dwukierunkowa lub po prostu ustalić sam fakt istnienia zależności bez wskazywania jej kierunku. Dzięki temu uzyskujemy narzędzie wspomagające tworzenie hipotez, a więc przechodzenie na wyższy poziom analizy konceptualnej zgodnie z zasadami metodologii teorii ugruntowanej.

Jeżeli chcemy stworzyć takie połączenie, należy wybrać określone elementy projektu oraz ustalić rodzaj związku (możemy go wybrać z już istniejących rodzajów zależności znajdujących się w zakładce Relationship Type w menu Clasifications lub stworzyć nowy rodzaj powiązania, wybierając odpowiednią opcję z menu New). Utworzone połączenie nie ma automatycznie przypisanych konkretnych segmentów materiału. Aby stworzyć takie powiązanie z daną partią materiału, należy wybrać odpowiednie dane, wykorzystując w tym celu funkcję Relationships. Zawsze też - zgodnie z duchem TU - istnieje możliwość reorganizacji istniejących powiązań i wprowadzenia zmian $w$ ich obrębie. See Also Links mogą być wykorzystywane do tworzenia związków między różnymi elementami projektu. W ten sposób, na zasadzie hiperłączy, otrzymujemy możliwość skojarzenia różnych informacji i ich zestawienia w hipotezy badawcze.

\section{Kodowanie materiału i tworzenie kategorii}

Kodowanie, a więc nadawanie etykiet partiom materiału i stopniowe przechodzenie na coraz wyższy poziom konceptualny, to jedna z podstawowych czynności badacza-analityka (Charmaz 2009). Przy czym kodowanie nie może być postrzegane jako po prostu indeksowanie danych, jest to bowiem niezwykle istotny element procesu analizy i interpretacji. Dzięki kodowaniu możemy w prosty sposób klasyfikować materiały źródłowe i ich fragmenty $\mathrm{w}$ określone tematy. Powstałe zaś kategorie są elementami projektu, grupującymi owe tematy, miejsca, osoby i inne interesujące badacza kwestie. Z tego względu twórcy CAQDAS, w tym NVivo, za jeden z głównych celów postawili sobie zapewnienie technicznych możliwości oraz wygodnego sposobu wykonywania czynności kodowania, a przede wszystkim ich zgodności z metodologią badań jakościowych. Program oferuje kilka opcji w tym zakresie, a każdy użytkownik, biorąc pod uwagę rodzaj wykorzystywanych metod oraz sposób organizacji pracy, znajdzie dla siebie takie, które najlepiej wpasują się w indywidualny styl i charakter pracy. Z tej perspektywy program NVivo wydaje się spełniać oczekiwania badaczy wykorzystujących $\mathrm{w}$ swoich analizach metodologię teorii ugruntowanej, zwłaszcza, że kodowanie i tworzenie kategorii czy ich łączenie stanowią znaczną część pracy analityka posługującego się TU. Wynikiem kategoryzacji i łączenia kodów w związki będące hipotezami jest budowanie teorii. Przy czym pierwszym poziomem pracy jest kodowanie otwarte, które ma kluczowe znaczenie w procesie analitycznym. Wykonywanie tego rodzaju kodowania w NVivo jest możliwe, gdy badacz będzie zaznaczał tekst fragment po fragmencie i nadawał określonym partiom materiału opisujące je etykiety, a więc kody.

W NVivo mamy podział na dwa rodzaje kodów. Pierwsze $\mathrm{z}$ nich to tak zwane wolne kody (Free Nodes), a więc takie, które nie znajdują się aktualnie w żadnym związku ani określonej zależności z innymi kodami. Zdaniem konstruktorów 


\begin{tabular}{|c|c|c|c|}
\hline Nodes & Look for: & Searchin & Firee Nodes \\
\hline D Free Nodes & \multicolumn{3}{|l|}{ Free Nodes } \\
\hline Cases & Name & Scurces & References \\
\hline Relationships & 8 storice & 1 & 1 \\
\hline Matrices & $\partial$ zachód & 0 & 0 \\
\hline 日) Search Folders & D pizyjemność & 0 & 0 \\
\hline all Nodes & tajemnica & 0 & 0 \\
\hline
\end{tabular}

Rys. 7. Rozwinięte menu Nodes i podgląd przykładowych Free Nodes

programu są one szczególnie wartościowe na W praktyce aby utworzyć wolny kod, należy początku analizy, pozwalają bowiem na robocze wybrać z menu głównego opcję New, a następokreślenie obszarów zainteresowańbadacza, któ- nie opcję Free Node In This Folder bądź w prostry nie widzi jeszcze na wstępnym etapie analizy szy sposób - ustawić kursor w obszarze robowzajemnych zależności i powiązań pomiędzy czym i naciskając prawy przycisk myszy, wykategoriami. Drugi rodzaj kodów, zasadniczy brać tę samą funkcję. Następnie wyświetli się w NVivo, to kody uporządkowane w określona okno dialogowe, w które powinniśmy wpisać strukturę (począwszy od kategorii centralnej), nazwę kodu oraz ewentualnie jego opis bądź która zawiera w sobie hierarchiczne posegrego- skrót nazwy - jeśli byłaby ona dłuższa i w ten wanie kategorii w tak zwane drzewo kategorii sposób utrudniała wyszukanie kodu. Taki kod kodowych (Tree Nodes) (Schönfelder 2011) ${ }^{6}$.

$6 \mathrm{~W}$ ramach kategorii (Nodes) występują także tak zwane przypadki (Cases), czyli kody z przypisanymi im „atrybutami", które to kody mogą reprezentować określone osoby bądź instytucje występujące $\mathrm{w}$ badaniu. $\mathrm{Z}$ kolei wspomniane już uprzednio relacje (Relationship) to, jak podaje wydawca oprogramowania, kody ze zdefiniowanymi połączeniami miedzy dwoma elementami projektu. W opcji menu głównego Nodes, oprócz wskazanych już możliwości, znajduje się także opcja Matrices, która

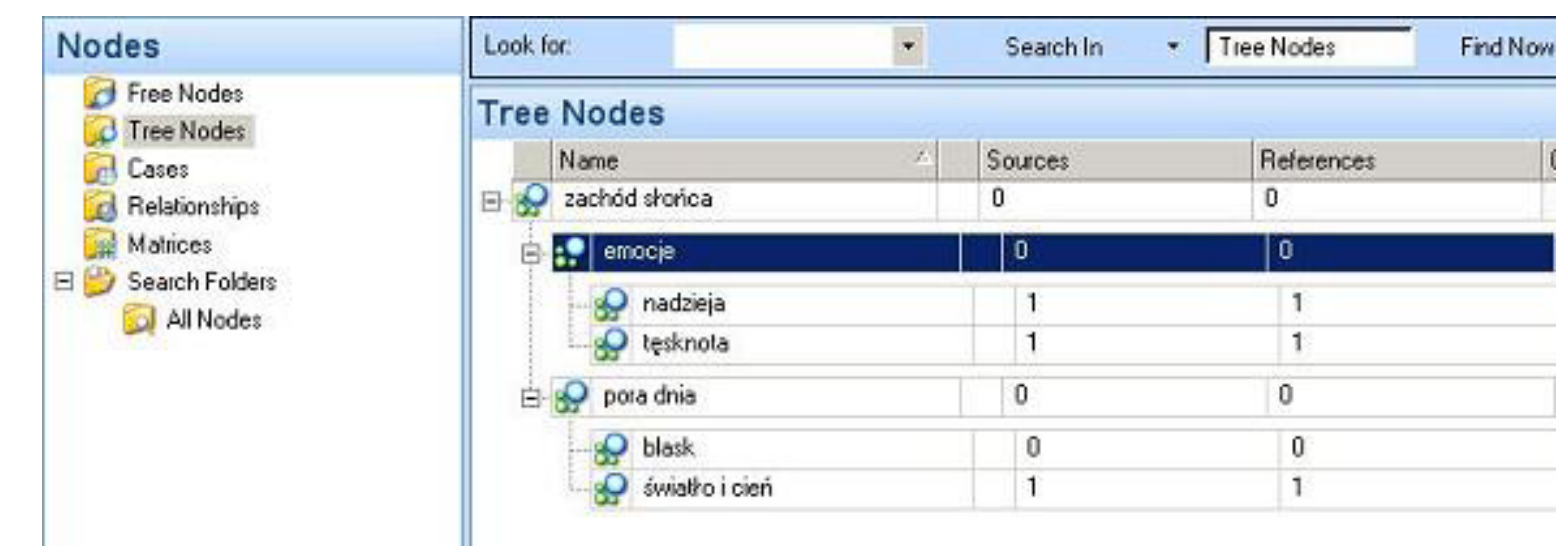

Rys. 8. System porządkownia kodów i kategorii (Tree Nodes) cego kodu w drzewie kodów kod niżej usytuowany w hierarchii, należy najechać kursorem na ów kod i naciskając prawy przycisk myszy, wywołać odpowiednią funkcję do tworzenia nowego kodu. Mamy też możliwość zmiany położenia kodów pozostających względem siebie na tym samym szczeblu struktury hierarchicznej, ale także możemy w każdej chwili dokonać przesunięcia, zmieniając ich usytuowanie $\mathrm{w}$ hierarchii. Istnieje także możliwość połączenia kodów w kategorie oraz łączenia ze sobą już istniejących kategorii (Saillard 2011).

Badacz, który wcześniej utworzył wolny kod (Free Node), a w toku analizy doszedł do wniosku, że dany kod wpisuje się w logiczną strukturę powiązań między kategoriami, może dokonać jego przeniesienia między folderami i przyporządkować go w dowolnym miejscu $\mathrm{w}$ drzewie kategorii kodowych (Tree Nodes).

Kodowanie może być wykonywane na tekście, jak również na tekstowych opisach zdjęć czy materiałów audio i wideo bądź może dotyczyć bezpośredniego kodowania pierwotnych (oryginalnych) źródeł danych. Kodować można więc każdy rodzaj danych 7 . Przeważnie są to już gotowe materiały $\mathrm{w}$ formie tekstowej, ewentualnie transkrypcje i opisy innego rodzaju danych (zdjęć, wideo), które w programie NVivo zostały przez badacza „przetworzone” na format tekstowy. W takim przypadku kodowanie będzie polegało na zaznaczeniu porcji materiału, której nadana zastanie określona etykieta bądź też, która będzie oznaczona kodem wybranym z już istniejących propozycji kodów.

Funkcja kodowania określonych segmentów tekstu (Code Selection) dostępna jest między innymi z poziomu menu kontekstowego i polega na wyborze jednej spośród trzech opcji: istniejącego kodu (At Existing Node), utworzenia nowego kodu (At New Node) bądź ostatnio używanego kodu zapisanego w pamięci podręcznej oprogramowania (At Current Node). Te same funkcje można wywołać, wykorzystując do tego celu od-

7 Warto w tym miejscu dodać, że kodowanie może dotyczyć określonych partii danych, ale też całego materiału źródłowego. Ta ostatnia opcja jest szczególnie użyteczna, gdy badacz zamierza potraktować cały materiał jako ilustrację jakiegoś poruszanego w badaniu wątku bądź, ze względu na rozłożone $w$ materiale akcenty - jest on zdecydowanie powiązany z daną kategorią.

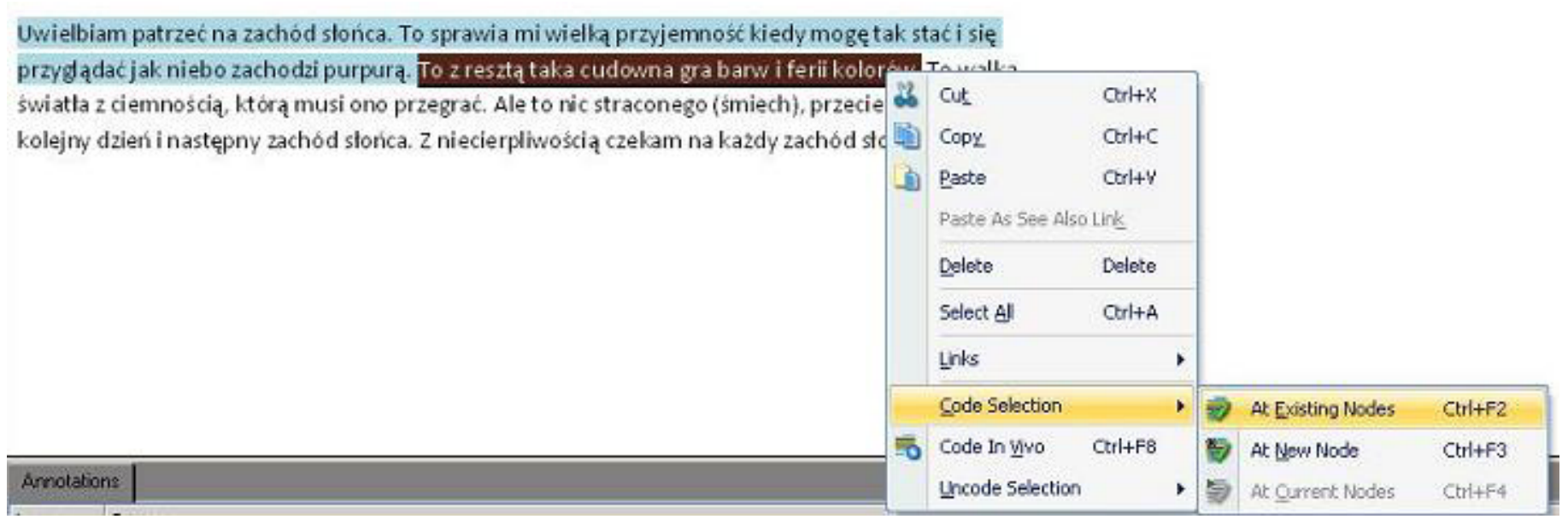

Rys. 9. Kodowanie materiałów tekstowych 


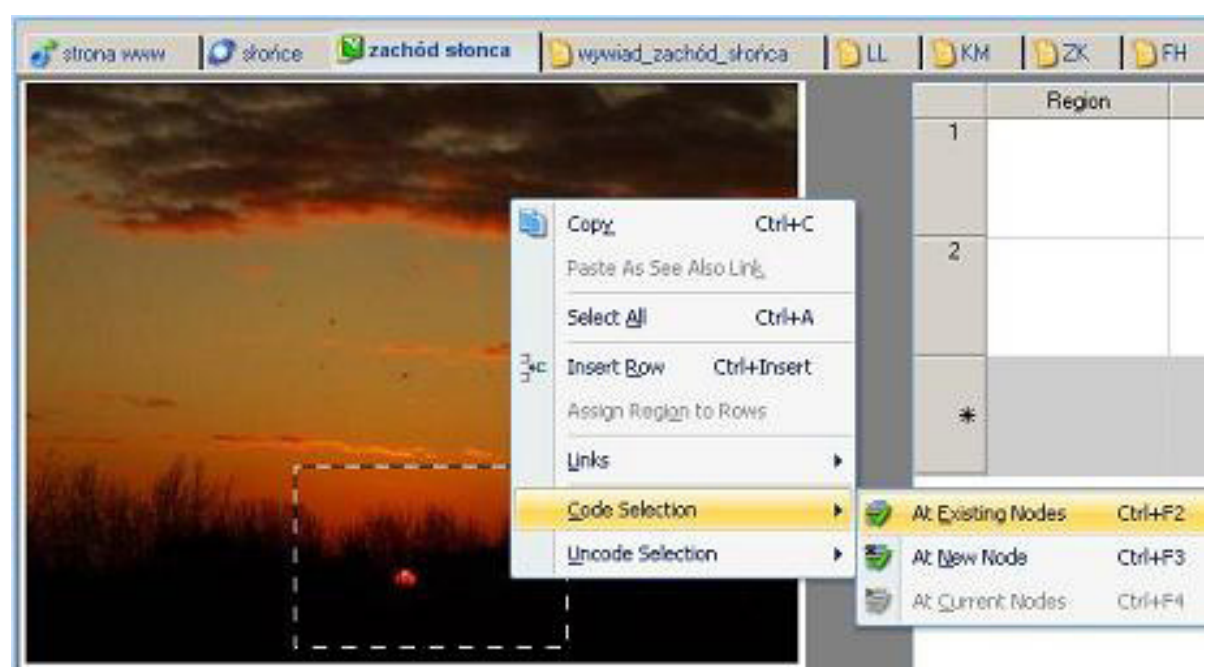

Rys. 10. Kodowanie zdjęć

powiednie skróty klawiszowe bądź korzystając z opcji Code w menu głównym.

Jeśli chcemy zakodować materiał zdjęciowy, wystarczy zaznaczyć określony jego fragment (co uwidacznia się zmianą koloru podświetlenia oznaczonego obszaru), a następnie wybrać odpowiednią opcję z menu kontekstowego bądź wywołać ją za pomocą skrótu klawiszowego.

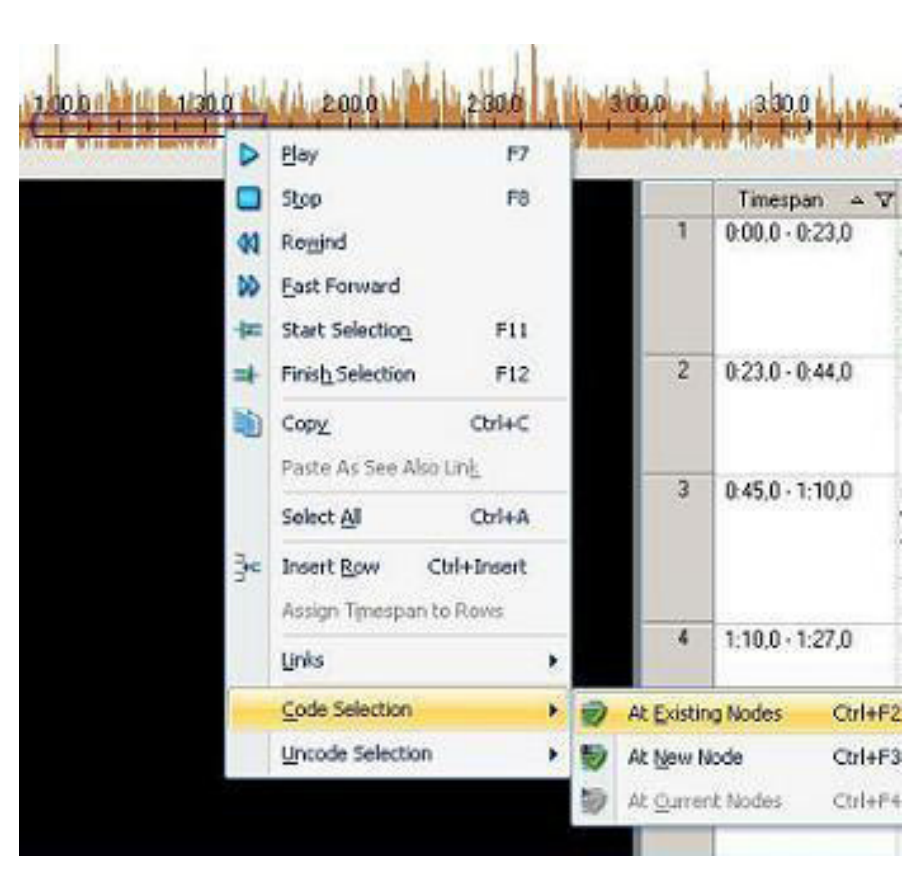

Rys. 11. Kodowanie materiałów audiowizualnych
Analogicznie jak z fotografią badacz może postąpić $\mathrm{z}$ materiałem audiowizualnym. W przypadku materiałów audio oraz wideo fragmenty, które badacz chce zakodować oznacza się na linii czasu (Timeline). Kodowanie polega na wybraniu fragmentu ścieżki audio/wideo poprzez oznaczenie początku oraz końca interesującego badacza fragmentu, któremu można - tak jak miało to miejsce w przypadku zdjęć - przypisać określoną etykietę (kod).

NVivo daje możliwość przeprowadzania kodowania na dwa sposoby: manualny oraz automatyczny. Możemy także, korzystając w opcji dostępnej w programie, tworzyć kody in vivo. Aby utworzyć taki kod należy zaznaczyć fragment tekstu i użyć odpowiedniego polecenia, co spowoduje pojawienie się kodu powiązanego właśnie z tym fragmentem danych. Nazwą kodu będzie, zgodnie ze specyfiką kodowania in vivo, zaznaczony uprzednio fragment tekstu. Specyfiką programu NVivo jest to, że tworzone przez badacza kody in vivo, będą automatycznie zamieszczane w folderze Free Nodes.
Kodowanie manualne jest podstawową formą kodowania danych. Badacz $\mathrm{w}$ tradycyjny sposób operuje zgromadzonym materiałem i analizując poszczególne treści, nadaje im samodzielnie określone etykiety, a wiec kody. Tworzenie kodów oraz przypisywanie fragmentom źródeł danych określonych kodów zostało już opisane powyżej. Ten sposób kodowania może być rozumiany - zgodnie z metodologią teorii ugruntowanej - jako kodowanie rzeczowe, w którym badacz stara się w sposób jak najbardziej rzetelny przedstawić $\mathrm{w}$ formie etykiet określone (najlepiej jak najmniejsze) segmenty danych. W ten sposób możliwe staje się przejście na wyższy poziom konceptualny, a badacz operuje już nie tylko na materiale źródłowym, ale przede wszystkim na informacjach zawartych w kodach i kategoriach analitycznych (Konecki 2000; Charmaz 2009).

Autokodowanie to kolejna możliwość kodowania, opierająca się na strukturze (formacie) informacji, na przykład kwestionariuszy, wywiadów czy opisów obserwacji. Używając funkcji autokodowania, można w szybki sposób utworzyć kody, bazując na stylach i strukturze tekstu oraz poszczególnych, wydzielonych w tekście para- grafach. Jest to funkcja szczególnie przydatna, gdy mamy do czynienia z dużą ilością materiałów o tożsamej strukturze. W celu użycia tej metody kodowania należy zaznaczyć te materiały (źródła danych), które chcemy zakodować, pamiętając, że wszystkie muszą mieć identyczny układ wewnętrzny i podobną strukturę. Aby wywołać tę funkcję, należy z menu Code wybrać opcję Auto Code lub kliknać na odpowiednią ikonę dostępną na pulpicie. Następnie wyświetli się nam okno wyboru opcji, w którym należy wskazać czy kodowanie będzie odbywało się na zasadzie podobieństwa stylu paragrafów, czy po prostu występowania paragrafów $\mathrm{w}$ tekście. Wybierając opcję stylu paragrafów, musimy następnie dobierać owe style do stylów nagłówków (Headings) w interesujących nas materiałach. Pozostaje jeszcze wybrać czy skorzystamy z już istniejących kodów, czy też wybierzemy możliwość utworzenia nowych kodów, których bazą będą określone partie materiału, występujące w przypisanych uprzednio formatach tekstu. Wybierając opcję tworzenia nowych kodów, możemy także na ich podstawie utworzyć nowe drzewo kodów. Powstała w ten sposób struktura drzewa

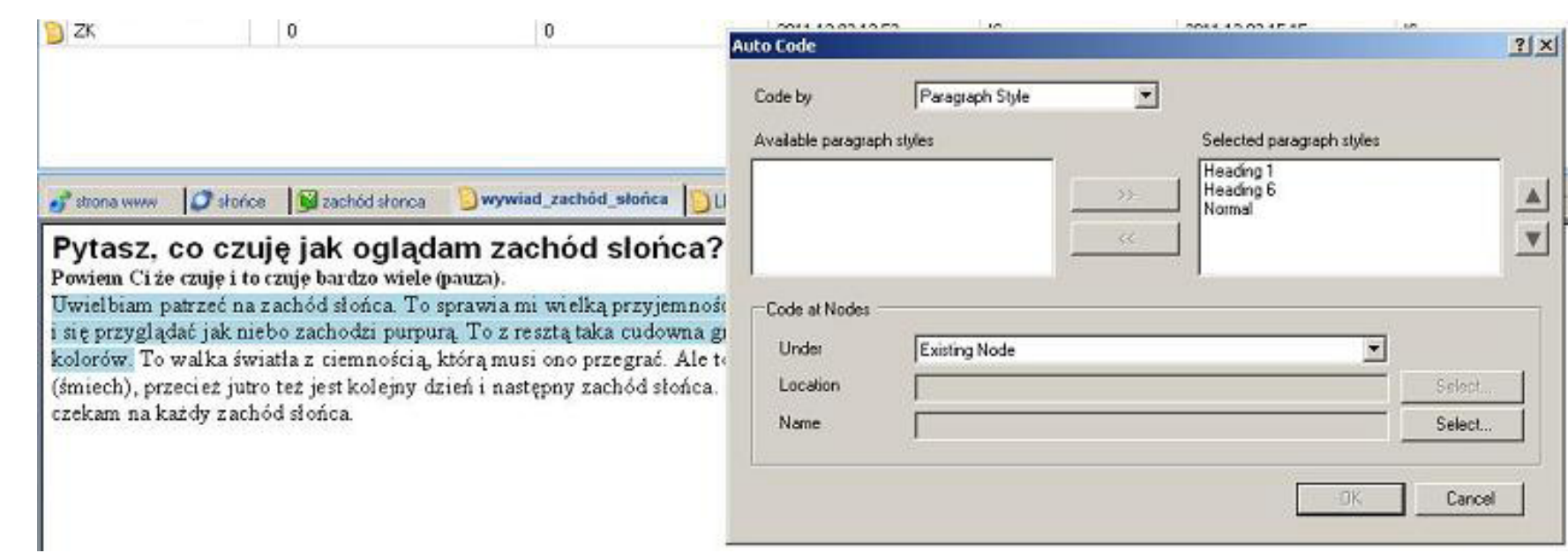

Rys. 12. Autokodowanie - system nagłówków i formatowania tekstu 
kodów będzie odwzorowaniem struktury tekstu (jego formatów i użytych nagłówków).

Ułatwieniem dla badacza stosującego NVivo jest możliwość wizualnego przedstawienia istniejących kodów i przypisanych do nich fragmentów materiałów. Można to osiągnąć za pośrednictwem pasków bądź systemu podkreśleń. Aby wywołać funkcję podkreśleń, należy z menu View wybrać opcję Highlights, a następnie jedną z dostępnych możliwości podkreślenia określonych szczegółów (np. zakodowanych określonym kodem fragmentów danych). W przypadku pasków (to rodzaj kolorowych linii, które odzwierciedlają sposób zakodowania partii materiału) sytuacja jest analogiczna, a aby wywołać ową funkcję, należy w menu głównym View wybrać opcję Coding Stripes i odpowiednią możliwość wyświetlania pasków. Funkcja ta, oprócz wizualizacji za pomocą kolorowych pasków kodów nadanych określonym partiom materiału, pozwala także na sprawdzenie "gęstości" zakodowania danego fragmentu, co zobrazowane jest poprzez intensywność szarego koloru paska (Wiltshier 2011).

Dane ilościowe i tworzenie zestawień $\mathrm{w}$ analizie jakościowej wspomaganej komputerowo - opcje przeszukiwania

Pakiety CAQDAS - jak sama nazwa wskazuje - służą do wspomagania pracy analityka posługującego się metodami jakościowymi. Temu właśnie celowi podporządkowana jest wewnętrzna architektura (a więc cały mechanizm oraz sposób działania) programu. Niemniej jednak większość pakietów CAQDAS posiada również wbudowane mechanizmy liczbowego opracowywania materiału. Są to przede wszystkim narzędzia do tworzenia wykresów i zestawień, pozwalające na prezentację danych w sposób ilościowy. Łącznie z zaawansowanymi możliwościami przeszukiwania danych pełnią one istotną rolę wspomagającą działania analityka, przy czym stopień i charakter wykorzystania owych funkcji będzie zależał od konkretnej metodologii, na jakiej opiera się badacz. W niektórych przypadkach, jak na przykład w sytuacji zastosowania TU, taki sposób opracowywania danych wydaje się być przydatny czy nawet uprawiony (trzymając się ściśle procedur analitycznych) jedynie

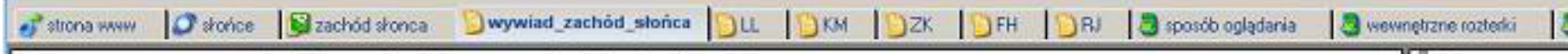

\section{Pytasz, co czuję jak oglaqdam zachód slońca?}

Powien Ci że cauje i to czuję bardzo wiele (pauza)

Uwielbram patrzéc na zachód stónca To sprawia mi wielka przyjemność kiedy moge tak stác

isę przygl àdać jak niebo zachodzi purpura To $z$ reszta taka cudowna gra barw i fenii

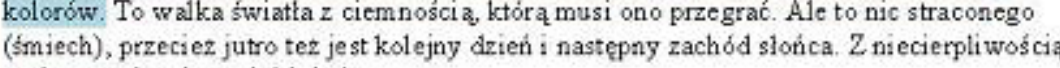

(smiech), przzeciez jutro tez jest
czekam na kazdy zachód stońca

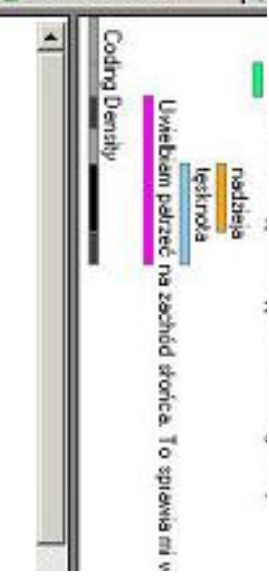

Rys. 13. Paski kodów w niewielkim stopniu, jeśli jednak będzie to źródłem interesujących spostrzeżeń, warto rozważyć go w procesie analizy danych (Schönfelder 2011).

Program NVivo posiada rozbudowaną funkcję przeszukiwania i tworzenia ilościowych zestawień wyszukiwanych słów (fraz) oraz kodów, a także częstotliwości ich występowania. Wyniki są wyświetlane $\mathrm{w}$ formie tabeli i mogą być przechowywane, drukowane lub eksportowane do innych programów, takich jak Microsoft Word bądź Excel. Ponadto NVivo zawiera oddzielny moduł do tworzenia wykresów w celu zilustrowania graficznego i liczbowego prowadzonej analizy.

W programie NVivo możemy wyszukać najczęściej występujące wyrazy (reprezentowane także

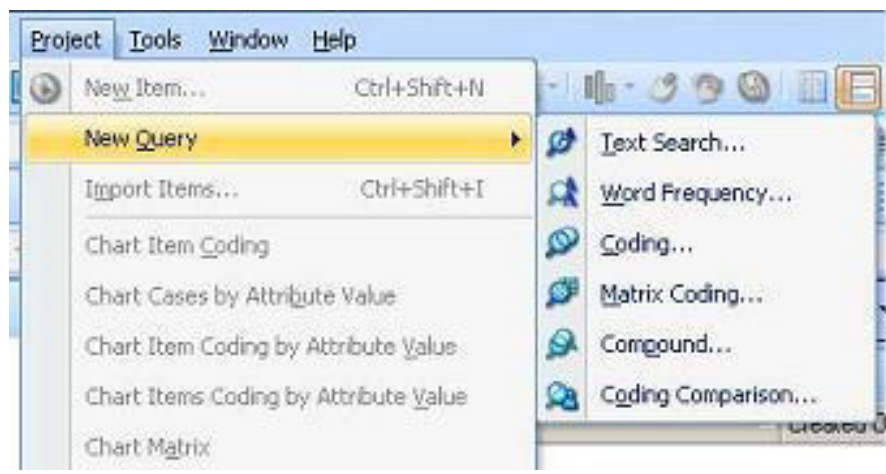

Rys. 14. Opcje przeszukiwania dostępne w rozwijanym menu

przez pojedyncze litery, jeśli są one np. spójnikami), wybierając minimalną długość słowa oraz wskazując, ile maksymalnie słów będziemy brać pod uwagę, licząc od najczęściej występującego. W ten sposób uzyskujemy podsumowanie, w którym wyodrębnione są poszczególne słowa uporządkowane według częstotliwości ich występowania. Dodatkowo widoczna jest informacja o tym, ile razy dane słowa pojawiły się w in-

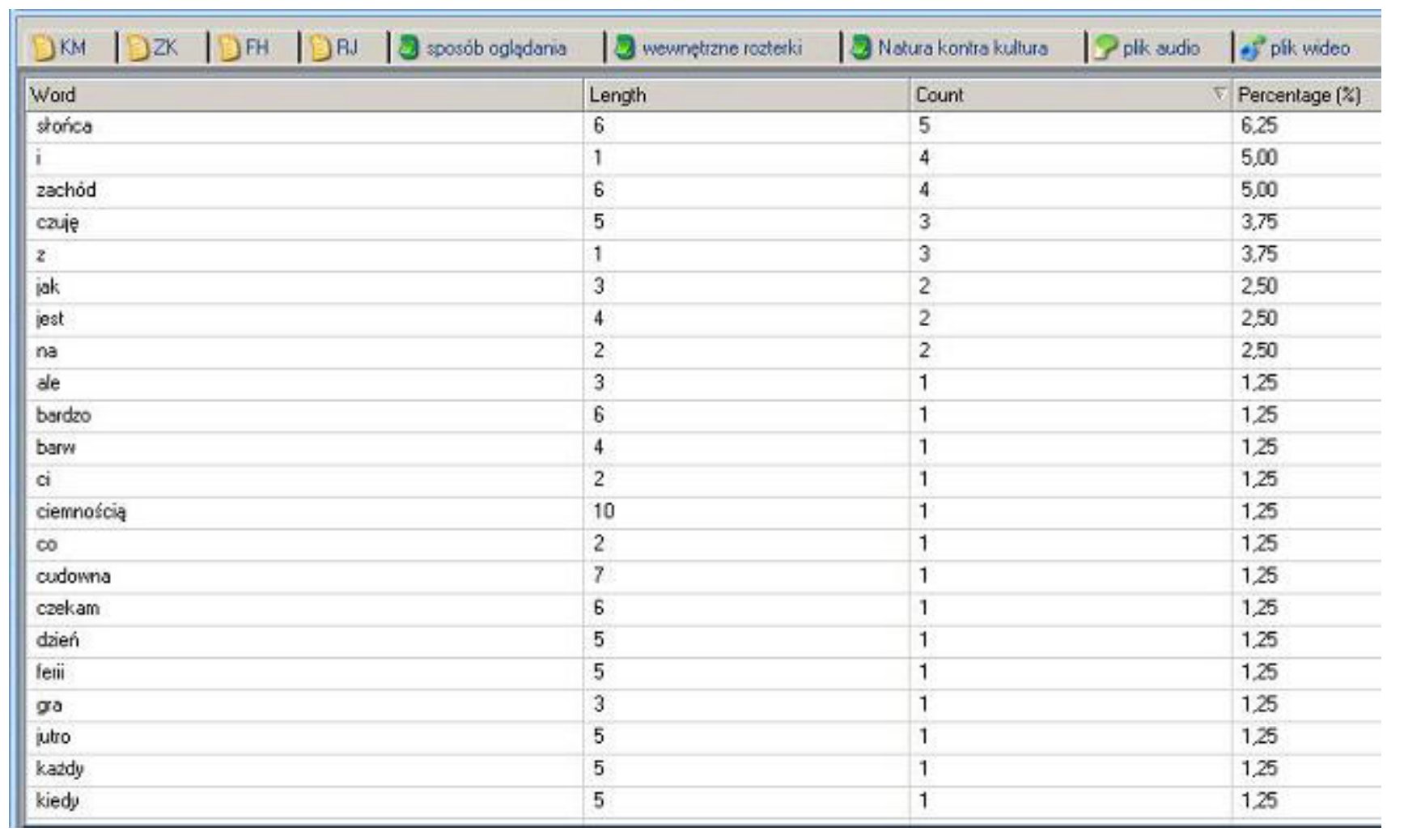

Rys. 15. Zestawienie częstotliwości występowania fraz i wyrazów w materiałach projektu 
teresującym badacza materiale oraz jaki stanowiło to procent $\mathrm{w}$ skali całego materiału.

Przechodząc do opcji Tag Cloud możemy zwizualizować częstotliwość występowania słów, co zobrazowane jest wielkością czcionki danego słowa. Przy czym w tym wypadku słowa uporządkowane są alfabetycznie, a wielokrotność

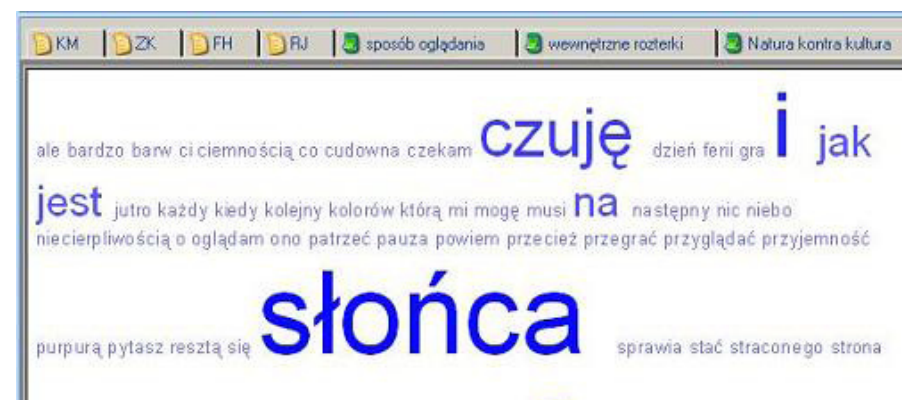

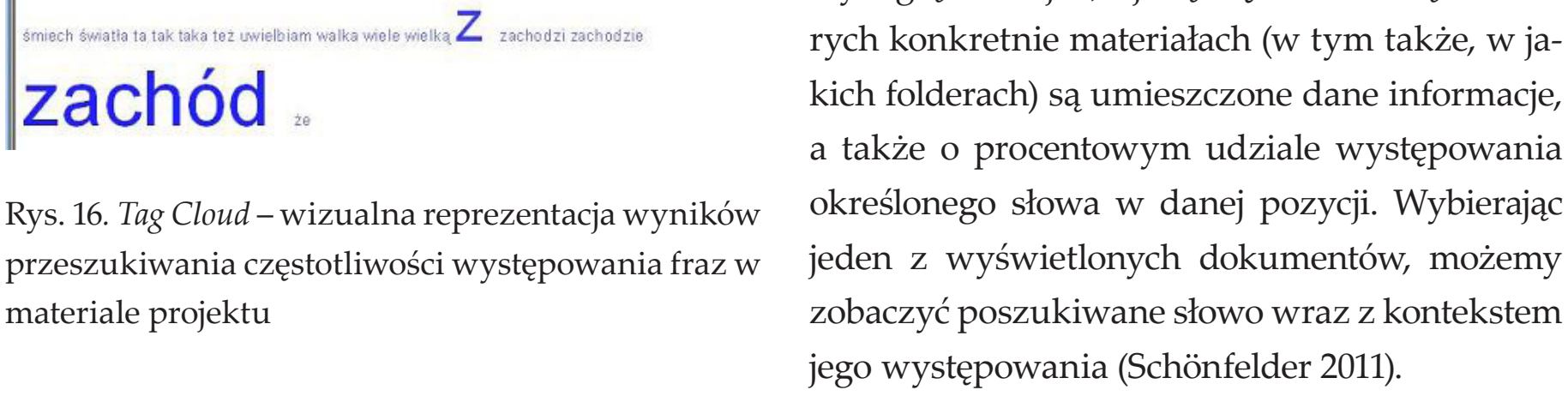

\begin{tabular}{|c|}
\hline A wyszykiwanie slow | \\
\hline 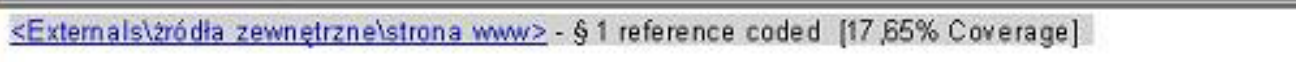 \\
\hline Reference 1 - $17,65 \%$ Coverage \\
\hline ta strona jest $\mathrm{Q}$ zachodzie słońca \\
\hline 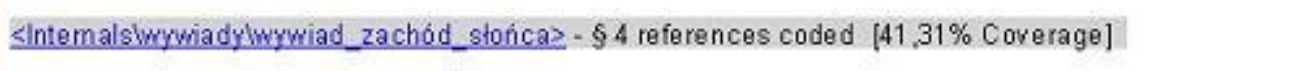 \\
\hline Reference $1-1,23 \%$ Coverage \\
\hline co czuję jak oglądam zachód slońca? \\
\hline Powiem Cize cruje i \\
\hline Reference $2 \cdot 37,63 \%$ Coverage \\
\hline to czuje bardzo wiele (pauza). \\
\hline $\begin{array}{l}\text { Uwielbiam patrzéc na zachód stońca. To sprawia mi wielka przyjemność kiedy moge tak stá́ } \\
\text { i się przygl adac jak niebo zachodzi purpura To z reszta taka cudowna gra barw i ferii } \\
\text { kolorów. To walka swatła z ciemnością }\end{array}$ \\
\hline
\end{tabular}

Rys. 17. Rezultat wyszukiwania określonego słowa w zamieszonych w projekcie danych

ich pojawienia się w materiale uwidacznia właśnie wielkość czcionki.

Inna dostępna $\mathrm{w}$ trybie wyszukiwania możliwość to przeliczanie częstości występowania słów oraz fraz, które znajdują się $\mathrm{w}$ różnych rodzajach materiałów dostępnych w bazie danych, przy czym w tym wypadku określamy, jakich dokładnie słów poszukujemy, wpisując słowo (słowa) w odpowiednim oknie przeszukiwarki. Dodatkowo w tej opcji możemy korzystać z różnych operatorów (łączników), jak na przykład OR lub AND w celu dookreślenia słów kluczowych, które interesują badacza. W rezultacie otrzymujemy wgląd w to jak, z jaką częstotliwością i w któa także o procentowym udziale występowania określonego słowa $\mathrm{w}$ danej pozycji. Wybierając zobaczyć poszukiwane słowo wraz z kontekstem jego występowania (Schönfelder 2011). nych zestawien czy matryc z połączenia par poszukiwanych słów i ich zbiorczego zestawienia, na przykład z danymi przypadkami.

Aby posłużyć się jedną z podanych powyżej funkcji, należy wykonać między innymi następujące czynności. Z menu kontekstowego należy wybrać opcję Project, a następnie zakładkę New Query i jedną z możliwości, które dostępne są w programie (są one także dostępne w menu Neww). Wybranie którejkolwiek z opcji powoduje wyświetlenie okna dialogowego, w którym należy wskazać parametry przeszukiwania i tworzenia zestawień. Wszystkie utworzone zestawienia zostają domyślenie umieszczone w folderze $Q u$ ery, skąd w prosty sposób można je przeglądać i nimi zarządzać.

Wybranie jednej z głównych opcji powoduje wyświetlenie okna, w którym znajdują się podstawowe informacje, takie jak nazwa oraz opis zestawienia dotyczącego wyszukiwanych informacji. Po wybraniu i zaakceptowaniu odpowiednich opcji przeszukiwania, ich rezultatem jest wyświetlenie okna podglądu, w którym znajdują się wszystkie istotne dla badacza informacje. Rezultaty wyszukiwania mogą również zostać włączone do zbioru materiałów projektu (funkcja Add To Project) i podlegać dalszej obróbce włącznie z kodowaniem.

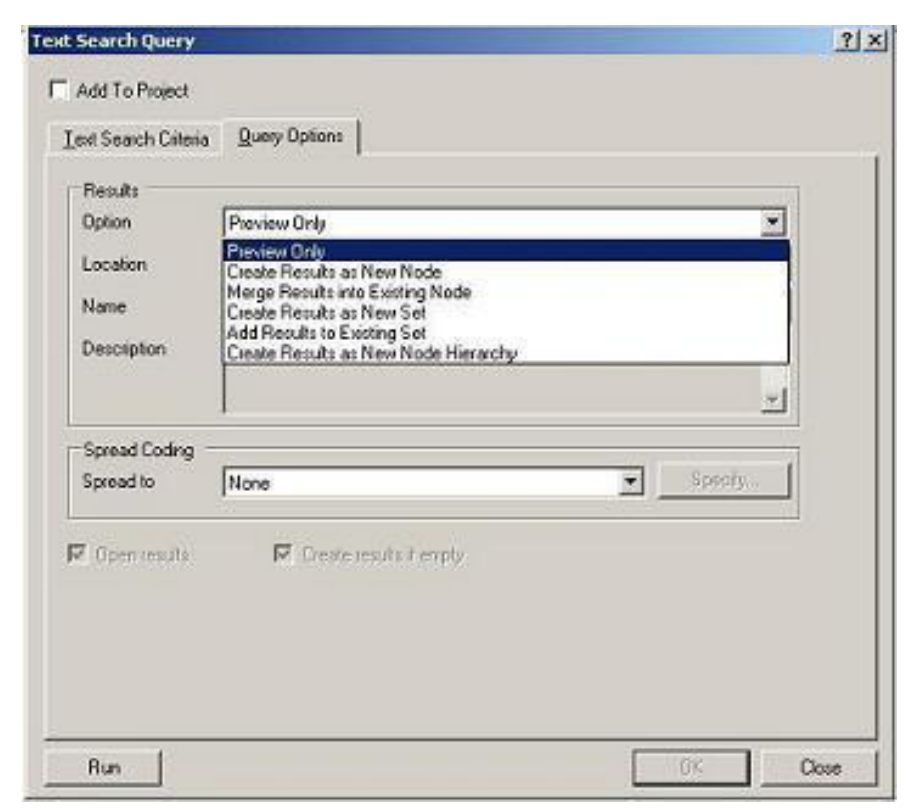

Rys. 19. Okno funkcyjne przeszukiwarki (wyszukiwanie wyrazów w danych)

Na zakończenie warto jeszcze dodać, że program NVivo pozwala badaczowi zainteresowanemu analizą ilościową na skorzystanie z opcji eksportowania materiałów, które następnie będą opracowywane $\mathrm{w}$ programach wspomagających analizę statystyczną, takich jak popularny 
MS Excel. Niemniej jednak w przypadku analizy prowadzonej zgodnie $\mathrm{z}$ metodologią teorii ugruntowanej tego rodzaju dane odgrywają niewielką rolę, stąd w niniejszym opracowaniu nie poruszamy szerzej tego wątku, odsyłając czytelników do publikacji innych autorów, traktujących te kwestie bardziej szczegółowo (zob. Richards 1999; 2005).

\section{Wizualizacje projektu: wykresy, modele i dia-} gramy

Wykresy (Charts) pozwalają wizualizować połączenia (związki i zależności) pomiędzy kodami i kategoriami, a także zestawienia powstałe w wyniku przeszukiwania treści.

Aby stworzyć wykres należy z menu Tools wybrać Charts (tę samą funkcję można wywołać, kli-

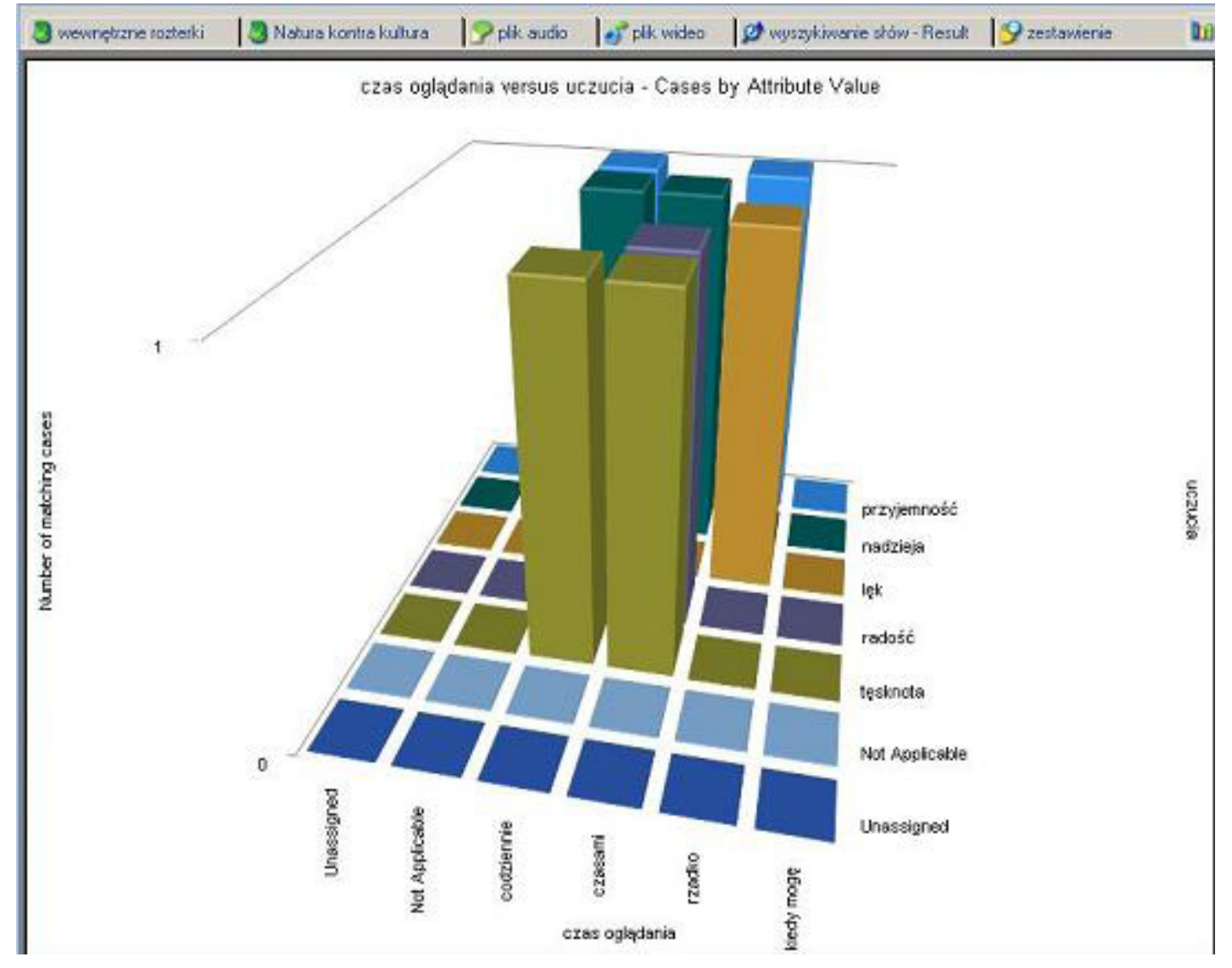

Rys. 20. Wykres powstały na bazie istniejących danych kając na odpowiednią ikonkę na pulpicie). W ten sposób uruchamiany kreator tworzenia wykresów z licznymi opcjami do wyboru. Następnie wybieramy określone parametry w oknie dialogowym. Po wybraniu stosownych opcji mamy możliwość wyświetlenia gotowego wykresu, który jednak nadal otwarty jest na modyfikacje, może ulec zmianie i reorganizacji pod wpływem nowych danych (Wiltshier 2011).

Program NVivo posiada także bardzo ważną z punktu widzenia metodologii teorii ugruntowanej opcję tworzenia modeli, które stanowią wizualizację kluczowych dla badacza elementów danych wraz z prezentacją powiązań między tymi elementami. Dzięki wykorzystaniu tej funkcji badacz może w sposób bardziej przejrzysty przedstawić szkic projektu bądź wizję swo- ich pomysłów związanych z opracowaniem materiału (Miles i Huberman 2000; Seale 2008).

Biorąc od uwagę względy praktyczno-techniczne, modele mogą być tworzone z różnego rodzaju dostępnych $\mathrm{w}$ programie figur geometrycznych (np. kwadrat, prostokąt, romb), które mogą (choć nie muszą) być dodatkowo zlinkowane $\mathrm{z}$ danym elementem projektu. Jednocześnie różnego rodzaju linie i strzałki stanowią wizualizację określonego rodzaju powiązań istniejących pomiędzy elementami projektu (por. Parker, Field Hoffman, Sawilowsky, Rolands 2011). Jeśli

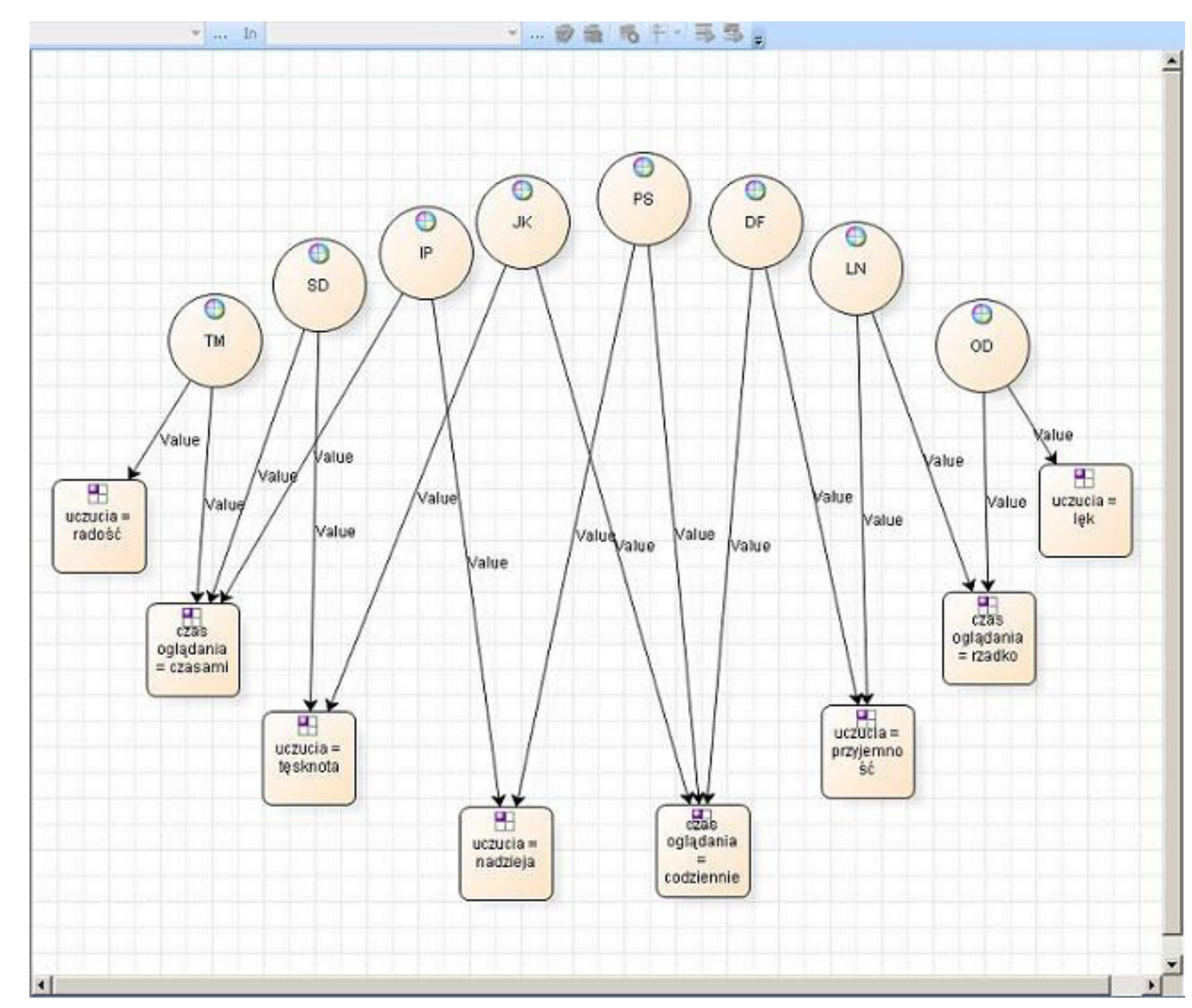

Rys. 21. Przykład modelu powstałego na bazie istniejących danych

dana figura geometryczna będzie reprezentować istniejący element projektu (np. kod, memo, zestawienie danych), wówczas w prosty sposób można wyświetlić jego zawartość klikając prawym przyciskiem myszy na ów kształt (Wiltshier 2011).

Cechą tak utworzonego modelu jest możliwość jego modyfikowania (wersja dynamiczna). Kiedy jednak zechcemy utworzyć rodzaj „migawki", a więc trwale zachować ustawienia danego modelu, wówczas nie będzie on już edytowalny i przyjmie postać statyczną. W konsekwencji

Przegląd Socjologii Jakościowej • www.przegladsocjologiijakosciowej.org 
jego kształty nie będą już związane (zlinkowane) z elementami projektu. Tym samym, jeśli będziemy wprowadzać jakiekolwiek zmiany i modyfikacje w elementach projektu, owe zmiany nie będą już odzwierciedlane w modelu. Jeśli badacz zechce utworzyć statyczny obraz modelu, musi z zakładki Project wybrać opcję Create As, a następnie Create As Static Model. W kolejnych krokach powinien wpisać nazwę i ewentualnie krótki opis modelu oraz potwierdzić chęć utworzenia takiego modelu. Poprzez utworzenie statycznego modelu badacz może utrwalić swoje pomysły i etapy kreowania nowych idei, do których zawsze może powrócić i sprawdzić, jakie zamiany zostały poczynione oraz jak $\mathrm{w}$ danym momencie kształtowały się jego pomysły analityczne. Opcja ta może być przydatna dla dokumentowania kolejnych etapów pracy analitycznej badacza (Bringer, Johnston, Brackenridge 2004).

Głównym polem działania badacza są jednak dynamiczne modele odzwierciedlające aktualne modyfikacje wynikające z procesu analitycznego i pokazujące bieżące pomysły analityka. NVivo umożliwia grupowanie poszczególnych elementów w większe całości (cząstkowe obszary całego modelu), a także ich wyświetlanie bądź ukrywanie - w zależności od potrzeb badacza.

Tworzenie nowego modelu rozpoczynamy od wyboru opcji New Model z menu Project. Następnie należy z menu Model wybrać opcję Add Project Items i zaznaczyć interesujące badacza elementy (takie jak kody, Memos, notatki, adnotacje, przypadki itd.). Kolejnym krokiem jest wybór danych, jakie mają zostać umieszczenie na modelu, a które są powiązane z wybranym uprzednio elementem (Children, Parents, Relationships,
See Also Links, Memo Links, Sources Coded). Praktyczną funkcją jest możliwość wyboru spośród czterech dostępnych sposobów wyświetlania elementów modelu: okrągłego, ukierunkowanego, ortogonalnego oraz hierarchicznego (menu Model i opcja Layout). Użytkownik może także w niemal dowolny sposób modyfikować kształty figur modelu, przesuwać figury względem siebie, zmieniać ich pozycję i wygląd. Podobnie można także zmieniać format czcionki, linii oraz kolor wypełnienia figur (menu Format, opcja Fill, Line). Oczywiście poza edycyjnymi zmianami badacz ma możliwość wprowadzenia modyfikacji w układzie modelu. Korzystając z opcji Add Associated Data, badacz może dodać nowy element modelu, który jest skojarzony z innym elementem mającym już swoją reprezentację $\mathrm{w}$ postaci figury geometrycznej. $\mathrm{W}$ ten sposób dany rodzaj informacji zostanie automatycznie zwizualizowany w postaci kształtu w modelu, a jego powiązanie $z$ określonym elementem będzie zobrazowane w postaci strzałki.

Istnieje także możliwość edytowania treści znajdującej się $\mathrm{w}$ figurach geometrycznych modelu. W tym celu należy w menu Model wybrać opcje Note Properties i dokonać stosowanej zmiany treści.

\section{Upowszechnianie wyników badań}

Niezwykle przydatną funkcją oferowaną w programie NVivo jest możliwość upowszechniania wyników przeprowadzonych za jego pośrednictwem analiz. Badacz może skorzystać z jednej z wielu dostępnych opcji eksportowania danych $\mathrm{w}$ formie czytelnej dla popularnych programów biurowych, takich jak Microsoft Office czy OpenOffice. Stosując dostępne rozszerzenia dla dokumentów tekstowych (.doc, .docx, .txt, .rtf, .pdf), badacz może eksportować dokumenty, memo, transkrypcje wywiadów i materiałów audiowizualnych czy podsumowania zawierające zestawienie danej kategorii i jej zawartości. W tym celu należy z menu Project wybrać opcję Export Document... (generalnie w przypadku eksportowania określonego rodzaju danych należy wybrać odpowiednią, aktywną opcję Export...), a następnie określić odpowiednie paramenty eksportowanego dokumentu (między innymi czy razem z dokumentem mają być eksportowane informacje o adnotacjach, relacjach i powiązaniach $z$ innym elementem projektu). W dalszej kolejności należy wskazać folder, do którego będzie eksportowany dokument oraz wybrać format jego zapisu. Opcję eksportowania dokumentu można także wywołać z menu kontekstowego prawym przyciskiem myszy, a następnie wybierając funkcję Export.

W analogiczny sposób należy postępować z eksportowaniem danych do arkuszy kalkulacyjnych, takich jak Microsoft Excel. Dzięki tej opcji badacz, który chce skorzystać z możliwości wsparcia analizy danych ilościowych oferowanych przez program NVivo bądź przeprowadzić takie analizy przy pomocy innego specjalistycznego oprogramowania (np. SPSS czy Statistica), może eksportować dane w postaci liczbowej. Do formatu XLS mogą być eksportowane między innymi materiały dotyczące struktury drzewa kategorii (Tree Nodes), zestawienia istniejących w projekcie przypadków (Cases), a także rezultaty użycia opcji przeszukiwania danych.

Sposobem upowszechniania danych jest także tworzenie raportów z badań, które mogą stanowić ilustrację pewnego etapu analizy bądź końcowego opracowania wyników badań. Aby utworzyć raport z aktualnego stanu analizy danych, należy w menu Tools wybrać funkcję Reports, a następnie jedną z dostępnych opcji (m.in. Project, Source czy Node Summary).

Ponadto badacz, który chce zawrzeć w swoim raporcie dane $\mathrm{w}$ postaci utworzonych $\mathrm{w}$ programie NVivo wykresów czy modeli, może skorzystać z opcji transformacji tego rodzaju elementów projektu do jednego z popularnych formatów zapisu zdjęć (np. JPEG, BMP, GIF). Działanie

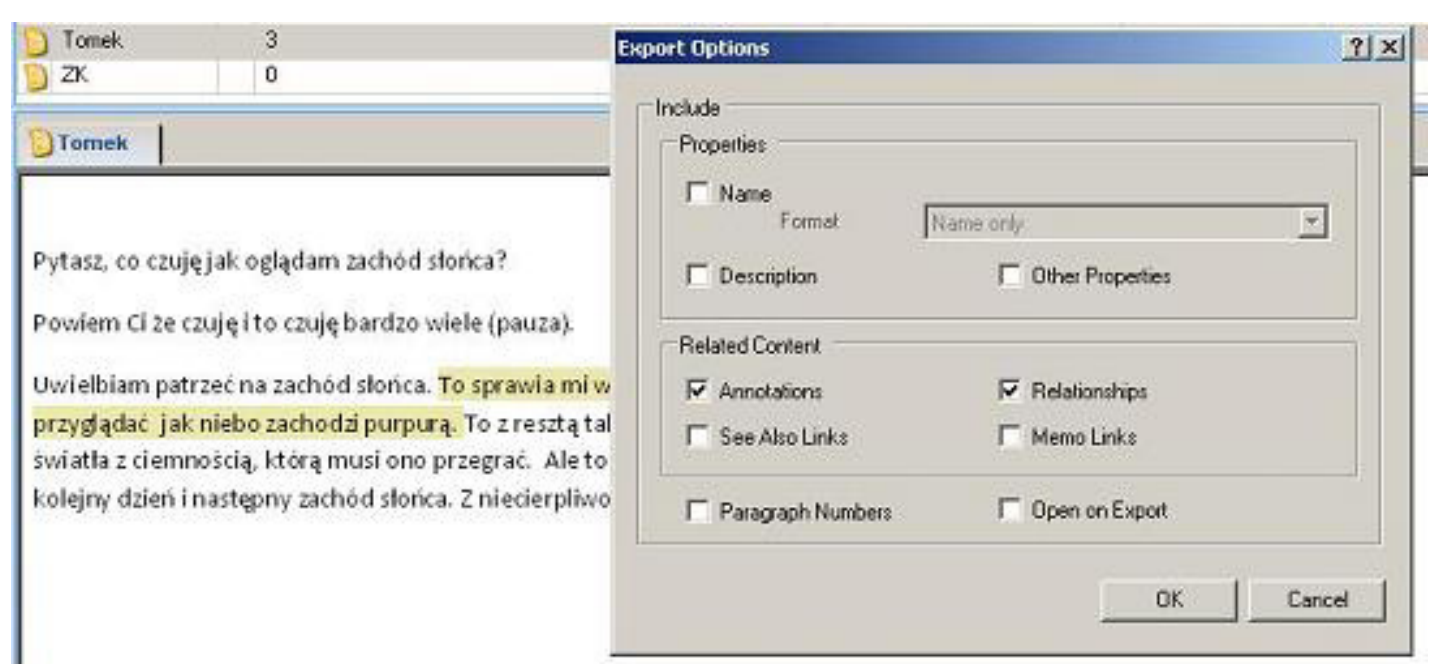

Rys. 22. Przykład eksportowania dokumentu tekstowego do formatu DOC 
to należy wykonać w sposób analogiczny do eksportowania dokumentów tekstowych oraz arkuszy danych liczbowych.

Badacz, który w szybki i łatwy sposób zechce dotrzeć do większej liczby odbiorców - w celu upowszechnienia wyników swoich badań - może

skorzystać z ciekawej opcji tworzenia ministron internetowych (mini-website). Do elementów projektu, które wraz z całą swoją zawartością (a więc powiązaniami, linkami, adnotacjami, memos itd.) mogą zostać w ten sposób wyeksportowane i zapisane $\mathrm{w}$ formacie HTML, należą między

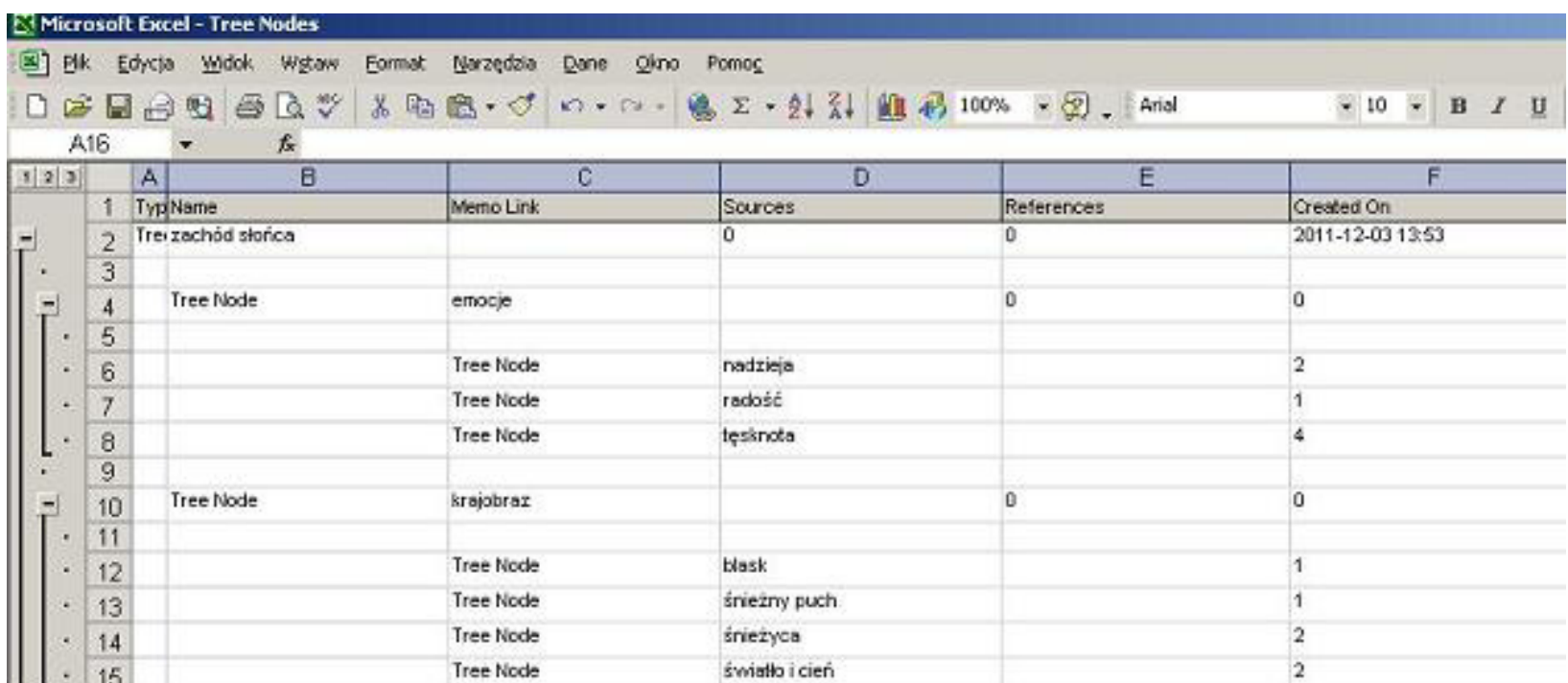

Rys. 23. Przykład wyeksportowanego drzewa kategorii do arkusza kalkulacyjnego programu Microsoft Office Excel (format XLS)

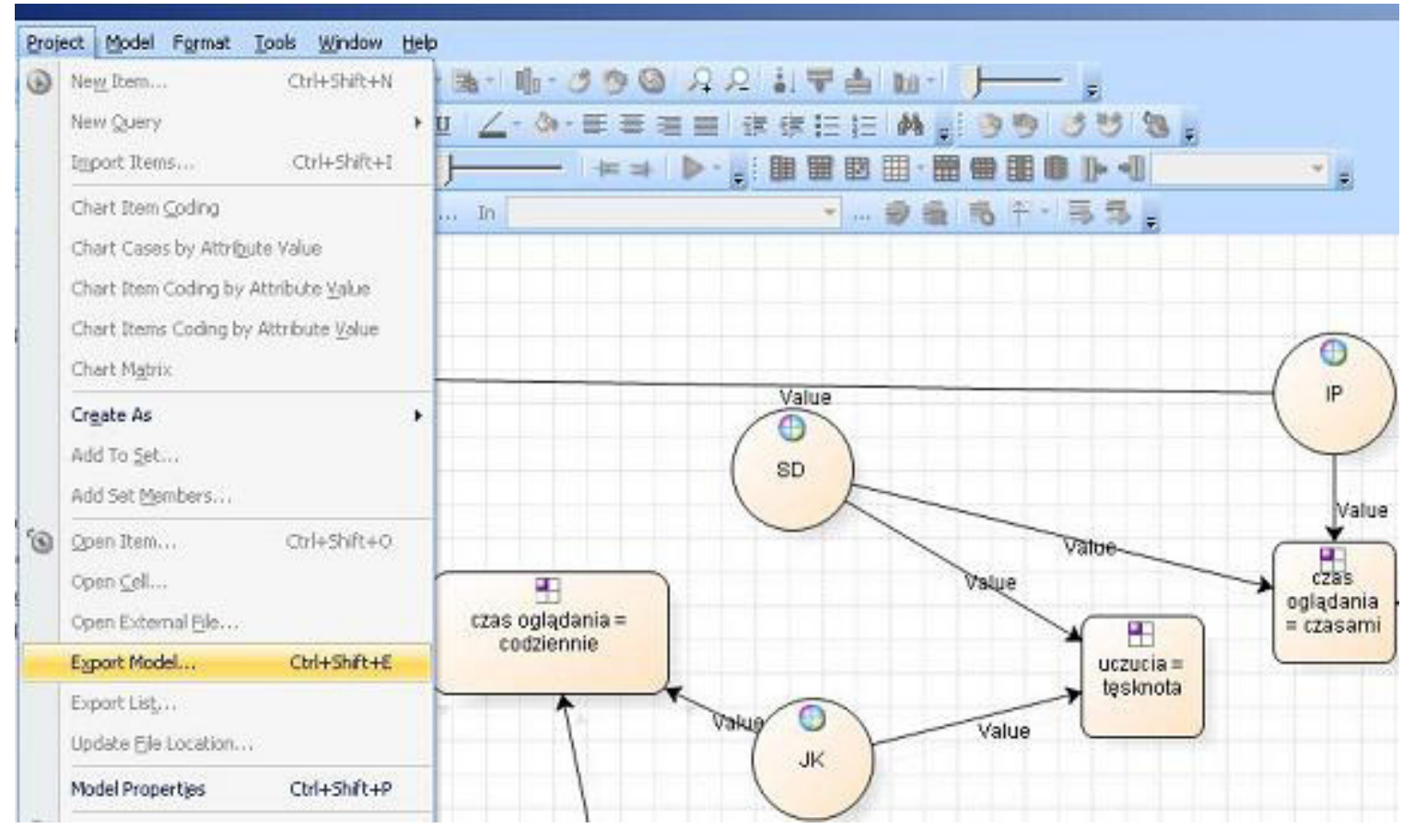

Rys. 24. Zapisywanie modelu utworzonego w programie NVivo do postaci zdjęcia

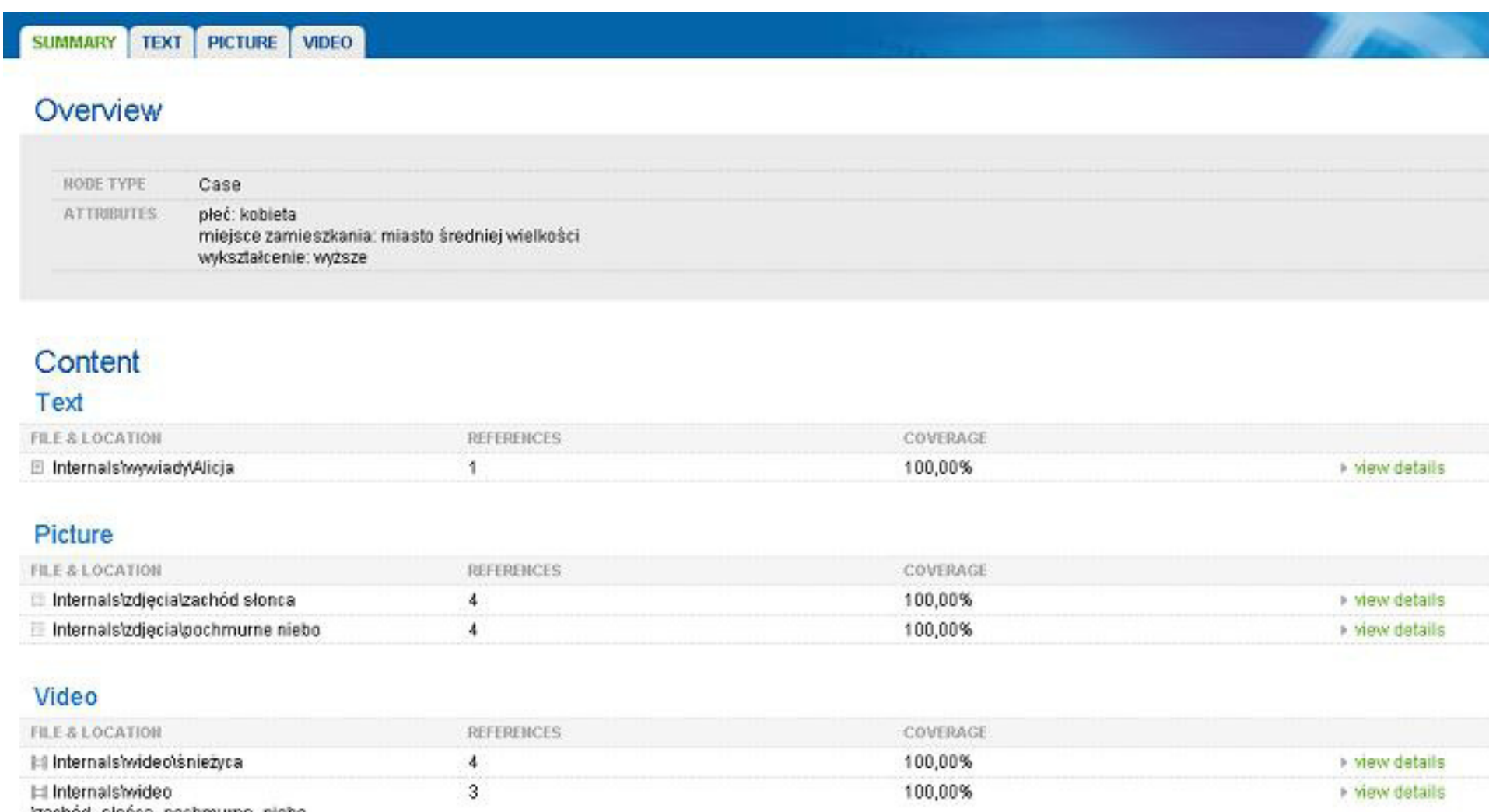

Rys. 25. Przykład ministrony internetowej utworzonej za pośrednictwem programu NVivo (na podstawie wybranego przypadku)

innymi wygenerowane kategorie bądź uprzednio zaimportowane (lub utworzone) w projekcie materiały źródłowe. Wykorzystanie tej funkcji pozwala badaczowi na rozpowszechnienie określonych informacji związanych z projektem oraz umożliwia szerokiemu gronu odbiorców wgląd $\mathrm{w}$ aktualny stan zaawansowania prowadzonej analizy danych.

Dla zilustrowania powyższych kwestii prezentujemy ministronę utworzoną na podstawie wybranego przypadku, dostępną pod linkiem ${ }^{8}$. http://www.qualitativesociologyreview.org/PL/ Volume18/Niedbalski_Slezak/Alicja.htm.

8 Ze względu na optymalne parametry stronę należy otwierać $\mathrm{w}$ przeglądarce Microsoft Internet Explorer, zezwalając jednocześnie na uruchomienie zablokowanych skryptów.
Zastosowanie programu NVivo w badaniach jakościowych - możliwości i ograniczenia

Programy CAQDAS mają za sobą długą drogę od prostych edytorów tekstu do zaawansowanych narzędzi kodowania, grupowania i łączenia różnych rodzajów danych. Ich obecny kształt jest rezultatem pracy wielu osób, zarówno informatyków czuwających nad technicznym zapleczem i konstrukcją narzędzi, jak i wielu lat doświadczeń użytkowników, którzy realizując własne badania, posługiwali się wcześniejszymi wersjami oprogramowania i jako praktycy wnieśli istotny wkład w jego rozwój, służąc radą i sugestiami, w jakim kierunku ów rozwój powinien zmierzać. Dzięki temu oprogramowanie CAQDAS, reprezentowane między innymi 
przez program NVivo, zdobywa coraz większą legitymizację naukowców i badaczy, co przejawia się chociażby poprzez obecność we współczesnych podręcznikach metod badań jakościowych rozdziałów dotyczących komputerowego wspomagania analizy danych. Spróbujmy więc zaprezentować główne zalety oraz ograniczenia, jakie wiążą się ze stosowaniem programu NVivo w praktyce badawczej.

Należy zauważyć, że niektóre z rozwiązań przyjętych w NVivo mogą być szczególnie ważne dla badaczy wykorzystujących metodologię teorii ugruntowanej, inne zaś będą pomocne niezależnie od tego, jakie podejście analityczne zastosowano w projekcie. Wśród zalet programu, które mogą zainteresować większość użytkowników istotne jest to, że oprogramowanie NVivo ułatwia pracę ze znaczną ilością zgromadzonych materiałów, które można dzięki niemu w prosty sposób przetwarzać, modyfikować, sortować i reorganizować, a także przeszukiwać. Jest to szczególnie ważne, ponieważ $\mathrm{w}$ badaniach jakościowych konieczność opanowania obszernej bazy danych niejednokrotnie stanowi wyzwanie samo w sobie (Hammerslay, Atknson 2000).

Zaletą oprogramowania NVivo jest także możliwość zorganizowania jednej bazy danych z różnego rodzaju materiałów źródłowych (Wiltshier 2011). NVivo umożliwia więc wykorzystanie wszystkich źródeł danych, jakie badacz pragnie włączyć do swojego projektu. Jest to praktyczne narzędzie pozwalające na wprowadzenie $\mathrm{w}$ życie postulatu B. Glasera all is data (rzecz jasna pod warunkiem, że dane dobierane są zgodnie z procedurą teoretycznego pobierania próbek) (Glaser 1978; Strauss, Corbin 1990; Glaser, Holton 2004; 2010).
Program NVivo umożliwia także minimalizowanie efektu redukcji informacji zawartych w materiałach empirycznych, co oznacza możliwość importowania materiałów audio i wideo oraz zdjęć z zachowaniem ich specyfiki oraz niuansów, jakie w sobie kryją (por. Miles i Huberman 2000). Każda bowiem ingerencja polegająca na ich przetworzeniu, na przykład transkrypcji nagrania wywiadu, będzie oznaczała utratę niektórych informacji. Dzieje się tak, ponieważ nie jesteśmy w stanie przełożyć subtelności przekazu mówionego czy tym bardziej wizualnego na ich transkrypcję czy opis (Rapley 2010). Innymi słowy, kiedy dwie osoby miałyby odtworzyć zdjęcie na podstawie jego opisu rezultaty ich działania byłyby znacznie bardziej zróżnicowane i odbiegające od oryginału, niż gdyby przedstawić owym osobom zdjęcie do wglądu, a następnie poprosić o jego pisemne odtworzenie. Dając możliwość włączenia pierwotnych źródeł danych do projektu, program NVivo sprawia, że takie straty są - na ile jest to możliwie - wykrywane i minimalizowane.

Ważną cechą programu NVivo jest to, iż pozwala on na porządkowanie różnych elementów projektu (zarówno materiałów źródłowych, jak i wszelkichinformacji będących wytworem badacza zaangażowanego w analizę danych - a więc de facto wytworów analizy). Jest to możliwe między innymi dzięki grupowaniu danych (źródeł) w osobne foldery, zgodnie z preferencjami badacza. A zatem w ramach oprogramowania wspierającego analizę jakościową użytkownik może wykorzystać bogate i rozbudowane opcje gromadzenia, ale też segregowania i porządkowania elementów projektu, zgodnie z założeniami i strategią badawczą (Seale 2008). Porządkowanie danych zapewnia badaczowi stałą kontrolę nad gromadzonym materiałem i pozwala na bieżąco śledzić występowanie podobieństw oraz różnic pomiędzy poszczególnymi przypadkami. Program NVivo ułatwia więc praktyczne działania związane z procedurą ciągłego porównywania, która, dając badaczowi podstawę do odkrywania ogólnych mechanizmów czy zakresu występowania określonych zjawisk i fenomenów społecznych (Glaser i Strauss 1967; Konecki 2000; Seale 2008), jest jedną z podstawowych procedur metodologii teorii ugruntowanej. Porównywanie przypadków, porównywanie pojęć z przypadkami obecnymi $\mathrm{w}$ danych, wreszcie porównywanie wygenerowanych pojęć, a więc kroki niezbędne w procesie budowania teorii (Glaser, Strauss 1967; Konecki 2000) wygodniej jest przeprowadzić, gdy kody są uporządkowane hierarchicznie $\mathrm{w}$ drzewo kodów, jak to jest $\mathrm{w}$ przypadku NVivo (Bringer, Johnston, Brackenridge 2006). Architektura programu niejako wymusza na badaczu nieustanne myślenie o związkach między kodami i kategoriami, ich porównywanie oraz modyfikowanie tworzonego przez badacza układu. Sprzyja także koncentracji na kategorii centralnej, wokół której powinny skupiać się działania badacza (Konecki 2000). Możliwość pisania różnego rodzaju notatek i tworzenia drzewa kodów sprzyja prowadzeniu systematycznej analizy. Rozwiązania te pozwalają więc uniknąć czyhającego na badaczy jakościowych zagrożenia, związanego z koncentrowaniem się jedynie na gromadzeniu danych $z$ pomijaniem ich pogłębionej analizy (Hammerslay, Atkinson 2000)

To, co przede wszystkim czyni NVivo interesującym dla analityków stosujących metodologię teorii ugruntowanej, to możliwość opracowania materiału zgodnie $\mathrm{z}$ logiką indukcyjnego postępowania badawczego. Oznacza to, że badacz wyposażony zostaje $\mathrm{w}$ takie funkcje i opcje oprogramowania, które pozwalają na podążanie ścieżką wiodącą od szczegółowych danych do wygenerowania ogólnych wniosków.

System notatek analitycznych, jaki proponują twórcy programu, pozwala na płynne przeplatanie działań związanych ze zbieraniem danych i ich analizą?. Jest to niezwykle ważne, gdyż generowanie teorii ugruntowanej jest procesem, którego powodzenie zależy $\mathrm{w}$ dużej mierze od pozytywnej synergii tych dwóch procedur (Konecki 2000). Generowanie teorii odbywa się stopniowo, stąd pomocne są takie rozwiązania programu NVivo, jak możliwość ciągłej modyfikacji wszystkich elementów projektu w miare pojawiania się nowych danych oraz brak konieczności stworzenia zamkniętej bazy przed rozpoczęciem analizy, co umożliwia dodawanie kolejnych danych $\mathrm{w}$ miarę ich gromadzenia (Bringer i in. 2006). Program NVivo umożliwia badaczowi płynne przechodzenie między kodowaniem otwartym, zogniskowanym, pisaniem memos, budowaniem modelu (Modeling). Narzędzia, w jakie wyposażony jest program pozwalają w czytelny sposób tworzyć oraz wizualizować powiązania między kategoriami (np. za pomocą hiperlinków) (Bringer i in. 2006). Tym samym może on wspomóc proces gromadzenia danych, analizowania i teoretyzowania (Bringer $i$ in. 2006). Oprogramowanie NVivo wyposażone jest więc w instrumenty, które znacznie ułatwiają spełnienie wymogów związanych

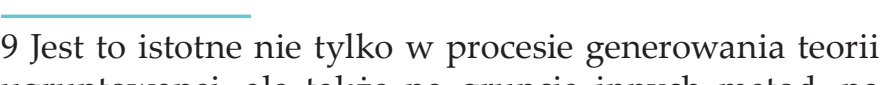
ncie innych metod, na przykład etnografii (Hammerslay, Atkinson 2000). 
z generowaniem teorii ugruntowanej, dostarczając badaczowi nowych narzędzi dbania o to, by powstająca teoria była dostosowana ( $f i t)$ do danych oraz dająca się modyfikować (modifiable) (Glaser 1978; Konecki 2000). Nie wyręczają one rzecz jasna badacza, jednak mogą ułatwić jego analityczne kroki od strony technicznej.

Na uwagę zasługują także rozbudowane możliwości wizualizacji wyników analizy prowadzonej za pomocą NVivo w postaci matryc, wykresów i diagramów. Jest to o tyle cenne, iż tworzenie diagramów integrujących wygenerowane kategorie i ukazujących związki między nimi pozwala uzyskać dystans do zebranych danych (Gorzko 2008) i jest ściśle powiązane z procesem generowania hipotez badawczych, a w konsekwencji budowania teorii wyjaśniających dane obszary rzeczywistości oraz objaśniających mechanizmy istnienia i funkcjonowania różnych fenomenów społecznych (Miles i Huberman 2000; Seale 2008).

Oprogramowanie NVivo wyposażone jest także $\mathrm{w}$ narzędzia ułatwiające wprowadzenie $\mathrm{w}$ danym projekcie badawczym procedur triangulacji danych, a także triangulacji badaczy (Konecki 2000). Na każdym z etapów analizy program NVivo umożliwia współpracę wielu osób zaangażowanych $\mathrm{w}$ jeden projekt dzięki takim funkcjom, jak na przykład: możliwość identyfikacji poszczególnych członków zespołu, obserwowanie i porównywanie działań poszczególnych użytkowników, w tym możliwość zweryfikowania, kto, kiedy i jakie dane dodał oraz jakie wprowadził modyfikacje $\mathrm{w}$ obrębie już istniejących elementów projektu. Niekwestionowaną zaletą tych rozwiązań jest możliwość sprawnego prowadzenia projektów w zespołach badawczych, których członkowie nie muszą pracować $\mathrm{w}$ tym samym czasie, lecz w dogodnym dla siebie momencie. Nie muszą być także fizycznie obecni w tym samym miejscu - najnowsze wersje programu NVivo umożliwią zdalną pracę na odległość. W ten sposób można tworzyć zespoły składające się z osób związanych z różnymi ośrodkami akademickimi i śledzić ich postępy oraz wkład w bieżące działania zespołu (Seale 2008; Wiltshier 2011). Jest to cenna możliwość, szczególnie jeśli weźmiemy pod uwagę coraz większe umiędzynarodowienie zespołów badawczych działających na przykład w ramach grantów finansowanych przez Unię Europejską. Możliwości, jakie daje program NVivo mogą pozwolić nie tylko na obniżenie kosztów prowadzenia analizy przez rozproszony zespół badaczy, ale także zwiększyć transparentność w zakresie podziału pracy oraz faktycznego wkładu poszczególnych członków zespołu w końcowy efekt analiz.

Dodatkową zaletą oprogramowania NVivo jest to, iż wszystkie etapy pracy analitycznej zapisane są w programie. W każdej chwili można prześledzić, jak rozwijała się myśl analityczna badacza, jakie wygenerował on kody, kategorie, memos. Pozwala to w przejrzysty sposób ukazać metodologiczne i analityczne zaplecze badacza w skali niemożliwej, a przynajmniej bardzo trudnej do osiągnięcia przy udziale tradycyjnych metod (Bringer, Johnston, Brackenridge 2004 za Morse, Richards 2002). Zastosowanie tego programu otwiera także nowe możliwości dla sposobu organizacji pracy podczas seminariów magisterskich czy doktorskich.

Z drugiej strony, pomimo wielu zalet przemawiających za zbieżnością wewnętrznej architektury oprogramowania i procedur $\mathrm{TU}$, owa struktura programu sprawia, że niektórzy badacze mogą zarzucić NVivo zbytnią sztywność i konieczność podporządkowania analizy rozwiązaniom zaimplementowanym przez konstruktorów oprogramowania. Biorąc zaś pod uwagę elastyczny i dość indywidualny przebieg każdego badania jakościowego, może się okazać, że oprogramowanie komputerowe zbytnio strukturalizuje i zawęża pole działania analityka, przez co jest sprzeczne z duchem metodologii badań jakościowych (Lonkila 1995; Seale 2008). Obawa ta wynika po części z tego, że pierwsze programy wspomagające analizę danych nie spełniały oczekiwań badaczy jakościowych i przyczyniły się do utrwalenia przekonania, że program komputerowy może prowadzić do zautomatyzowania analiz i pomijania pogłębionej interpretacji danych (Bringer i in. 2004). Jednakże w przypadku oprogramowania NVivo wydaje się być to raczej kwestią sposobu wykorzystania możliwości programu przez danego użytkownika ${ }^{10}$, nie zaś samej architektury oprogramowania. Badacz $\mathrm{w}$ dalszym ciągu musi bowiem interpretować, konceptualizować, dokumentować kolejne kroki analizy i generować teorię. Jeśli w zakresie tych działań pojawią się błędy czy zaniedbania, wina będzie leżała po stronie analityka, nie zaś narzędzia komputerowego, które jedynie wspomaga, ale nie wyręcza badacza w jego działaniach (Bringer i in. 2004).

Swoistym paradoksem jest fakt, iż niektórzy użytkownicy mogą czuć się przytłoczeni sze-

10 Odrębną kwestia jest zarzut formułowany przez niektórych krytyków, iż nowoczesne technologie bywaja wykorzystywane nie dla ich faktycznych możliwości, ale w celu wykreowania wizerunku danego badacza czy proektu jako innowacyjnego. $W$ takich sytuacjach program CAQDAS pełni jedynie rolę dekoracyjną lub też stosowany jest bezrefleksyjnie, bez świadomości jego interakcj z wybraną metodologią (Travers 2009). rokim spektrum zastosowań i możliwości, jakie oferuje NVivo. Program posiada długą listę funkcji, które znacznie przewyższają potrzeby przeciętnego odbiorcy, zaś liczba dostępnych opcji może dla niektórych, zwłaszcza niedoświadczonych użytkowników, stanowić wyzwanie, szczególnie przy pierwszym zetknięciu z oprogramowaniem. Takie rozbudowanie funkcji programu wynika z tego, że nowoczesne pakiety CAQDAS muszą spełniać wymagania różnych podejść metodologicznych i sprostać potrzebom tak poszczególnych naukowców, jak również grup badawczych pracujących nad tym samym projektem. Mimo ich wielości, użyteczność funkcji jest bezsporna, a większość badaczy jakościowych (niezależnie od wykorzystywanej ramy metodologicznej) prawdopodobnie spodziewa się znaleźć je w pakiecie CAQDAS (por. Schönfelder 2011). Poza tym wydaje się, że ci badacze, którzy obeznani są ze środowiskiem komputerowym w ogóle i reprezentują co najmniej średni stopień zaawansowania w zakresie posługiwania się powszechnie dostępnymi rodzajami oprogramowania (jak na przykład narzędzia Microsoft Office), nie powinni odczuwać dyskomfortu w pracy z programem NVivo. Tym bardziej, że producenci starają się jak najbardziej ułatwić użytkownikowi pracę z programem i uczynić posługiwanie się oprogramowaniem oraz dostęp do poszczególnych funkcji intuicyjnym.

Należy także pamiętać, że programy CAQDAS zawierają wiele opcji wspierających analize związaną z kodowaniem (np. kody in vivo lub zdefiniowane przez badacza, kodowanie w sposób indukcyjny lub dedukcyjny, manualny bądź z wykorzystaniem opcji autokodowania), wy- 
szukiwaniem danych, tworzeniem linków do memos, dokumentów, kategorii, wizualizowaniem związków (na przykład wykresów, zastawień i modeli). Istnienie wielu opcji nie oznacza, że każdy użytkownik w każdym projekcie musi wykorzystać je wszystkie. Badacz powinien być świadomy metodologicznych konsekwencji użycia poszczególnych funkcji i rozsądnie wybierać te spośród nich, które są zgodne z przyjętą przez niego metodologią (por. Bringer i in. 2004).

Krytycy wysuwają także argument, że skoro oprogramowanie NVivo jest narzędziem uniwersalnym, a więc takim, które może być wykorzystywane przez badaczy reprezentujących rozmaite szkoły i projektujących swoje badania przy zastosowaniu różnych metod jakościowych, może się okazać, że nie jest ono w pełni dostosowane do żadnej z metod badawczych. Wielu analityków uważa, że programy CAQDAS (w tym NVivo) w należyty sposób wspierają strategię badań właściwą dla metodologii teorii ugruntowanej $j^{11}$ (Lonkila 1995; Bringer i in. 2006), lecz są mało przydatne $\mathrm{w}$ badaniu niewielkich fragmentów tekstu, zazwyczaj wykorzystywanych $\mathrm{w}$ analizie dyskursu, przede wszystkim zaś analizie konwersacyjnej (Seale 2008). Krytycy wskazują także, że nie jest możliwe wykorzystanie $\mathrm{w}$ pełni zalet programu, jeśli będzie on używany do projektów badawczych opartych na niewielkiej bazie danych, złożonej na przykład z kilku wywiadów (Travers 2009). Istnieje

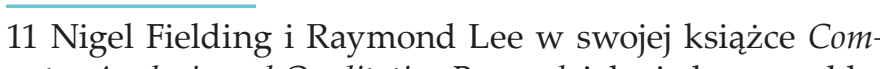
puter Analysis and Qualitative Research jako jeden z problemów wskazywanych przez użytkowników programów CAQDAS wymieniaja zbyt silny wpływ metodologi teorii ugruntowanej na sposób projektowania tych programów. Jednakże, jak zauważaja sami autorzy, wraz z rosnącym zaawansowaniem aplikacji, maleje ich stopien zależności od jakiegokolwiek podejścia analitycznego
(Gibbs 2011 za Fielding, Lee 1998). więc ryzyko, że konkretny program może okazać się nieprzydatny do danego projektu badawczego (Angrosino 2010). Jednak to ryzyko można zminimalizować, jeśli badacz zapozna się ze specyfiką różnych rodzajów oprogramowania CAQDAS i wybierze to, które najlepiej będzie spełniać jego oczekiwania.

Kolejna kwestia wysuwana przez sceptyków to fakt, iż posługiwanie się oprogramowaniem komputerowym wymaga od badacza nie tylko metodologicznej i teoretycznej sprawności, ale także zapoznania się ze specyfiką konkretnego programu i jego funkcjami. Analityk, który chce wykorzystać NVivo musi z konieczności poświęcić trochę czasu i wysiłku, by oswoić się z możliwościami programu. Jest to szczególnie ważne dla początkujących badaczy, którzy rozpoczynając projekt, często nie znają ani specyfiki oprogramowania, ani metodologii, którą wybrali. W takich sytuacjach wykorzystanie pakietów CAQDAS może wydłużyć czas przygotowywania projektu (Bringer i in. 2006). Należy jednakże zauważyć, że coraz częściej zajęcia przybliżające zasady obsługi oprogramowania CAQDAS znajdują się w programach nauczania studentów z zakresu nauk społecznych (Bringer i in. 2004). Prawdopodobnie więc dla kolejnych pokoleń badaczy prowadzenie badań przy wykorzystaniu wspomagania komputerowego będzie działaniem naturalnym. Zdarza się również, że niechęć do oprogramowania wspierającego analizę danych związana jest z pewnymi barierami czy osobistymi i naukowymi uprzedzeniami w stosunku do możliwości oferowanych przez nowoczesne technologie informatyczne (Angrosino 2010). Wobec tego przed zakupem konkretnego oprogramowania CAQAS warto zadać samemu sobie pytania o poziom, na jakim dany badacz potrafi sobie radzić $\mathrm{z}$ komputerem, typ projektu, jaki zamierza przeprowadzić, rodzaj danych, jaki będzie gromadził i metodologię, jaką chciałby zastosować (Bringer i in. 2006).

Ostatnią barierą, jaka pojawia się w kontekście korzystania z oprogramowania CAQDAS, jest jego cena. Ten fakt oraz konieczność posiadania sprzętu komputerowego o odpowiednich parametrach generuje (spore) koszty finansowe, jakie musi ponieść badacz, który zechce posługiwać się $\mathrm{W}$ swojej pracy takim narzędziem ${ }^{12}$. $\mathrm{Z}$ tego względu tym bardziej należy zachęcać, by osoby zainteresowane NVivo, zanim dokonają zakupu licencji, wypróbowały to oprogramowanie w udostępnionej przez producenta 30-dniowej wersji testowej.

\section{Podsumowanie}

Korzystanie w projektach badawczych z oprogramowania NVivo jest pomocne ze względu na kilka aspektów działań analityka. Pozwala na systematyczną pracę z wykorzystaniem dużych zbiorów różnych rodzajów danych, które można importować do projektu i grupować na wiele sposobów za pomocą folderów, zestawień i przypadków. W ten sposób uzyskujemy dostęp do danych, łatwo i szybko możemy zorientować się, co zostało już wykonane i na jakim etapie zaawansowania prac znajduje się badacz.

NVivo w prosty sposób umożliwia wyszukiwanie słów i fraz, szybkie przeglądanie zakodowa-

12 Na szczęście obecnie istnieje wiele darmowych bądź stosunkowo niedrogich programów wspomagających analize jakościowa, jednak te najbardziej zaawansowane echnologicznie, które oferują szereg przydatnych funkcji, są płatne. nych materiałów czy systematyczne śledzenie dynamiki zmian. Program pozwala także na zidentyfikowanie i odkrywanie nowych elementów za pomocą funkcji przeszukiwania. Natomiast narzędzia do wizualizacji dają sposobność spojrzenia na poszczególne informacje z nowej perspektywy. Za pomocą NVivo możemy także pracować w zespole, a każdy z jego członków jest w stanie działać na własną rękę, a następnie połączyć swoje dokonania z wynikami innych uczestników projektu.

Z tej perspektywy program NVivo pozwala na wykonywanie określonych działań związanych $\mathrm{z}$ procesem analitycznym, które $\mathrm{w}$ takim wymiarze, ani w tak relatywnie krótkim czasie nie były możliwe przy zastosowaniu tradycyjnych sposobów prowadzenia badań.

Celem niniejszego artykułu nie jest jednak udowadnianie wyższości analizy z wykorzystaniem komputera i oprogramowania nad tradycyjnymi działaniami badacza. Chcemy natomiast wskazać, że obok metod tradycyjnych istnieją również te, które z powodzeniem mogą wykorzystywać nowoczesne technologie. Tym samym pragniemy zwrócić uwagę, że komputerowe wspomaganie analizy danych jakościowych nie oznacza najlepszego sposobu projektowania i prowadzenia badań, lecz stanowi pewną alternatywę w stosunku do tradycyjnych metod ich wykonywania. To, jakiego wyboru dokona badacz powinno zależeć od jego osobistych preferencji, rodzaju badań oraz charakteru eksplorowanego terenu. W gruncie rzeczy najważniejsze wydaje się nie to, jaki będzie ostatecznie sposób realizacji badań - tradycyjny czy z zastosowaniem CAQDAS - ale to, aby wybrane techniki, metody i narzędzia pracy były najlepiej dopasowywane 
do zaplanowanych przez badaczy działań (Seale 2008).

Należy jednak zauważyć, że coraz powszechniejsze wykorzystywanie CAQDAS wpływa na kształt projektów badawczych i być może wyznacza kolejny etap na drodze rozwoju i ciągłego ewaluowania metodologii jakościowej. Przy czym, tak jak każdą metodę należy stosować świadomie i z odpowiednią wiedzą oraz namysłem badawczym, tak samo i po wszelkiego rodzaju oprogramowanie wspomagające proces analizy jakościowej należy sięgać w sposób refleksyjny. W innym przypadku, bez względu na charakter projektu badawczego - tradycyjny czy z wykorzystaniem oprogramowania komputerowego - prawdopodobnie pojawią się problemy z jego realizacją. Oprogramowanie CAQDAS (w tym NVivo) nie wyręczy badacza $z$ jego działań analitycznych i nie wykona ich w sposób automatyczny (Lonkila 1995). Jeśli rezultaty projektu badawczego, w którym wykorzystano oprogramowanie komputerowe wspierające analizę nie są zadowalające, jest to efekt pracy badacza analityka, a nie wada programu (por. Silverman 2008). Jedynym odpowiedzialnym za poziom analizy i jakość wygenerowanej teorii pozostaje badacz (Bringer i in. 2006).

$$
\text { *** }
$$

Każda zmiana dotycząca sposobu organizacji badań może wywoływać wśród analityków mieszane uczucia. Pojawić się mogą zarówno jej orędownicy, jak i przeciwnicy, a każda z tych grup będzie wysuwała argumenty na poparcie swojego stanowiska. Wobec oprogramowania komputerowego wspomagającego analizę jakościową pewną obawę mogą czuć osoby, które po prostu nie znają oprogramowania lub nie czują się dobrze w roli użytkowników nowoczesnych technologii. Posługiwanie się programami CAQDAS wymaga pewnej znajomości działania komputerów i umiejętności posługiwania się różnymi opcjami, jakie oferuje sprzęt i narzędzia należące do rodziny nowych mediów (Kubinowski 2010). Wydaje się, że programy CAQDAS są kolejnym krokiem na drodze ewolucji metod badań społecznych. Obecnie możemy obserwować niezwykle dynamiczny rozwój oprogramowania komputerowego mającego wspierać różne etapy jakościowych projektów badawczych. Programy te są nieustannie reorganizowane, udoskonalane, wzbogacane o nowe funkcje. Przyszłość pokaże, czy na stałe zagoszczą one w świadomości większości badaczy jakościowych, czy też powstaną inne, alternatywne sposoby i kierunk rozwoju metod badań jakościowych, w tym metodologii teorii ugruntowanej.
Bibliografia

Angrosino Michael (2010) Badanie etnograficzne i obserwacyjne. Przełożyła Maja Brzozowska-Brywczyńska. Warszawa: Wydawnictwo Naukowe PWN.

Bieliński Jacek, Iwańska Katarzyna, Rosińska-Kordasiewicz Anna (2007) Analiza danych jakościowych przy użyciu programów komputerowych. „ASK”, nr 16, s. 89-114.

Bringer Joy D., Johnston Lynne H., Brackenridge Celia H. (2004) Maximizing Transparency in a Doctoral Thesis1: The Complexities of Writing About the Use of QSR*NVIVO Within a Grounded Theory Study. ,"Qualitative Research", vol. 4, no. 2, s. 247-265 [dostęp 10 października 2011]. Dostępny w Internecie: http:// qrj.sagepub.com/content/4/2/247.

------ (2006) Using Computer-Assisted Qualitative Data Analysis Software to Develop a Grounded Theory Project. „Field Methods”, vol. 18, no. 3, s. 245-266 [dostęp 10 października 2011]. Dostępny w Internecie: http:// fmx.sagepub.com/content/18/3/245.

Charmaz Kathy (2009) Teoria ugruntowana. Praktyczny przewodnik po analizie jakościowej. Przełożyła Barbara Komorowska. Warszawa: Wydawnictwo Naukowe PWN.

Clarke Adele (2005) Situational Analysis: Grounded Theory After the Postmodern Turn. Thousand Oaks, London, New Delhi: Sage.

Denzin Norman K., Lincoln Yvonna S., red., (2009) Metody badan jakościowych, t. 1. Wyd. pol. pod red. nauk. Krzysztofa Podemskiego. Warszawa: Wydawnictwo Naukowe PWN.

Flick Uwe (2010) Projektowanie badania jakościowego. Przełożył Paweł Tomanek. Warszawa: Wydawnictwo Naukowe PWN.
Gibbs Graham (2011) Analizowanie danych jakościowych. Przełożyła Maja Brzozowska-Brywczyńska. Warszawa: Wydawnictwo Naukowe PWN.

Glaser Barney G. (1978) Theoretical Sensitivity. San Francisco: The Sociology Press.

Glaser Barney G., Strauss Anselm L. (1967) The discovery of grounded theory. Strategies for qualitative research. Chicago: Aldine Publishing Company.

Glaser Barney G., Holton Judith (2004) Remodeling grounded theory .,Forum: Qualitative Social Research", vol. 5, no. 2 [dostęp 15 września 2011]. Dostępny w Internecie: 〈http://www.qualitative-research.net/index.php/fqs/article/view/607.

------ (2010) Przemodelowywanie teorii ugruntowanej. Przełożyli Marek Gorzko i Łukasz Pyfel. „Przegląd Socjologii Jakościowej”, t. 6, nr 2, s. 81-102 [dostęp 15 września 2011]. Dostępny w Internecie: http:// www.qualitativesociologyreview.org/PL/Volume13/ PSJ_6_2_Glaser_Holton.pdf\%.

Gorzko Marek (2008) Procedury i emergencja. O metodologii klasycznych odmian teorii ugruntowanej. Szczecin: Wydawnictwo Naukowe Uniwersytetu Szczecińskiego.

Hammerslay Martin, Atkinson Paul (2000) Metody badań terenowych. Przełożył Sławomir Dymczak. Warszawa: Wydawnictwo Zysk i S-ka.

Knoblauch Hubert, Flick Uwe, Maeder Christoph (2005) Qualitative Methods in Europe: The Variety of Social Research. „Forum Qualitative Sozialforschung / Forum: Qualitative Social Research", vol. 6, no. 3 [dostęp 30 września 2011]. Dostępny w Internecie: http://www.qualitative-research.net/index.php/fqs/ issue/view/1. 
Konecki Krzysztof T. (2000) Studia z metodologii badań jakościowych. Teoria ugruntowana. Warszawa: Wydawnictwo Naukowe PWN.

Kubinowski Dariusz (2010) Jakościowe badania pedagogiczne. Lublin: Wydawnictwo UMCS.

Lonkila Markku (1995) Grounded theory as an emerging paradigm for computer-assisted qualitative data analysis [w:] Udo Kelle, ed., Computer-Aided Qualitative Data Analysis. London: Sage, s. 41-51.

Miles Matthew B., Huberman Michael A. (2000) Analiza danych jakościowych. Przełożył Stanisław Zabielski. Białystok: Transhumana.

Parker Dawid R., Field Hoffman Sharon, Sawilowsky Shlomo, Rolands Laura (2011) Self-Control in Postsecondary Settings: Students' Perceptions of ADHD

College Coaching. "Journal of Attention Disorders", December 15, [dostęp 30 grudnia 2011]. Dostępny $\mathrm{w}$ Internecie: http://jad.sagepub.com/content/early/2011/12/13/1087054711427561.

Rapley Tim (2010) Analiza konwersacji, dyskursu i dokumentów. Przełożyła Anna Gąsior-Niemiec. Warszawa: Wydawnictwo Naukowe PWN.

Richards Lyn (1999) Using NVivo in Qualitative Research. London, Los Angeles: Sage.

----- (2005) Handling Qualitative Data: A Practical Guide. London: Sage Publications.

Saillard Elif K. (2011) Systematic Versus Interpretive Analysis with Two CAQDAS Packages: NVivo and MAX$Q D A$. „Forum: Qualitative Social Research”, vol. 12, no. 1 [dostęp 30 września 2011]. Dostępny w Internecie: http://www.qualitative-research.net/index.php/ fqs/article/view/1518.

Schönfelder Walter (2011) CAQDAS and Qualitative Syllogism Logic-NVivo 8 and MAXQDA 10 Compared.
"Forum: Qualitative Social Research”, vol. 12, no. 1 [dostęp 30 września 2011]. Dostępny w Internecie: http://www.qualitative-research.net/index.php/fqs/ article/view/1514

Seale Clive (2008) Wykorzystanie komputera w analizie danych jakościowych [w:] David Silverman, red., Prowadzenie badań jakościowych. Warszawa: Wydawnictwo Naukowe PWN, s. 233-256.

Silverman David (2008) Prowadzenie badań jakościowych. Przełożyły Małgorzata Głowacka-Grajper, Joanna Ostrowska. Warszawa: Wydawnictwo Naukowe PWN.

Strauss Anselm L., Corbin Juliet (1990) Basics of Qualitative Research. Thousand Oaks, London, New Delhi: Sage Publications.

Travers Max (2009) "New Methods, Old Problems" A Sceptical View of Innovation In Qualitative Research "Qualitative Research", vol. 9, no. 2, s. 161-179 [dostęp 30 września 2011]. Dostępny w Internecie: http://qrj. sagepub.com/content/9/2/161

Wilk Katarzyna M. (2001) Komputerowe wspomaganie jakościowej analizy danych. „ASK”, nr 10, s. 49-63.

Wiltshier Fiona (2011) Researching With NVivo. „Forum: Qualitative Social Research", vol. 12, no. 1 [dostęp 12 września 2011]. Dostępny w Internecie: http://www.qualitative-research.net/index.php/fqs/ issue/view/36.

\section{Qualitative data analysis using the NVivo programe and the application of the methodology of grounded theory procedures}

The main aim of the article is to identify the capabilities and constraints of using CAQDAS (Computer-Assisted Qualitative Data Analysis Software) programs in qualitative data analysis. Our considerations are based on the personal experiences gained while conducting the research projects using the methodology of grounded theory (GT) and the NVivo 8 program. In presented article we focused on relations between the methodological principles of grounded theory and the technical possibilities of NVivo 8. The paper presents our opinion about the most important options available in NVivo 8 and their application in the studies based on the methodology of grounded theory.

Keywords: CAQDAS (Computer-Assisted Qualitative Data Analysis Software), NVivo 8, qualitative methods, methodology of grounded theory 